\title{
ファジイシステムモデリング通覧
}

\section{中島 信之*}

\section{まえがき}

私は1999年 9 月から 1 年間, カナタ・トロント大学 の Türksen 教授のもとで遊学する機会を得た。教授の 専門であるファジィシステムモデリングは私にとって 全くの未知の分野だったが, せっかくの機会を生かさ ないテはないと思い, 勉強してみることにした。研究 室の大学院生に紹介してもらって, 初为て手にした論 文が Sugeno and Yasukawa [83] である.

こういういい方をしてなんだが,一読魅了された。 これはひとつ腰を落として読んでみなければなるまい と決心し，同論文の参考文献を手始如に読むべき論文 を芋づる式につぎつぎと追い求めてみた。

最初は単に読むだけのつもりだったが，読んでいる うちに，整理がつかなくなり，自分のためにもまとめ るという作業の必要性を感じた。幸い自由な時間はた つぷりあった。読みながらまとめ，まとめながらさら に文献を漁るという生活であった。読みまとめるうち に, 主題の全容が明らかになっていく過程には快感が あった。この通覧はその結果である．まだまだ不十分 ではあろうが、このあたりでおおかたの批判を仰ごう と思う。

なお，最近 Nguyen and Sugenoの編書が刊行され た。まだ十分目を通す機会をもっていない，本通覧の 意困はこれとは違い，ファジィシステムモデリング全 般を広く浅く眺めることにある。この分野の全貌を知 $\eta ， 1 つ 1 つ の$ 研究の, 全体の中における位置づけを 明らかにできれば幸いである。

\section{1 序}

\section{ファジィシステムモデリングとは}

そもそもファジィシステムモデリングとは何かとい う問いはそう答えやすい問いではない。ひとつには， ファジィシステムモデリングのもつ多義性による。 た とえばファジィによるシステムモデリングなのか，フ

$\dagger$ An Overview on Fuzzy System Modeling

Nobuyuki NAKAJIMA

* 富川大学 経済学部 释虽学科

Toyama University
アジィシステムのモデリングなのか，判然としないと いうのもそうである。本稿では，前者，すなわちファ ジィ理論（論理）による（複雑システムの）モデリン グを指すことにする.

システムモデリング（モデル化）とは，システムの 挙動 behavior，すなわち，システムの状態ないしその 変化を記述することである，ただ，システムの状態は 直接観察しがたい。そこで，観測可能でしかもシステ ムの状態を反映するそこからの出力に注目し，それを 過去のいくつかの時点での入力と状態（出力）とから 再現できれば，システムの挙動を記述できたと，ほほ いえる。

以上をまとめると，システムモデリングとは，出力 がどういう仕組みで得られるかを記述する（あるいは 再現する）ことであり，ファジィシステムモデリング とはファジィ理論（論理）によるシステムのモデリン グということである。

\section{ファジィシステムモデリングを証み知る}

まず Sugeno and Yasukawa [83] がある。これは IEEE Trans. Fuzzy Systems 創刊号の（実質上の）巻 頭論文である。ファジィ論理に基づく質的モデリング が詳しく，かつきわめて明快に解説されている.

これに先んじて Tong [90］がある.Kim et al. [42] (第II章), ファジィシステムモデリングの歴史を概観 した Joo et al. [36]，あるいはファジィ制御について 概説したTong [88］などもファジィシステムモデリン グとは何かを知るのに適している。

日本語によるものでは，中森の著書 [60]，古橋その 他による解説（[66]，第11章) などがある。

最近（'98年） Nguyen and Sugeno 編によるファジ イシステムモデリングに関する書 [63］が刊行された。

\section{ファジィシステムモデリング略史}

システムに関する研究は1950-60年代に始まる.

だが，ファジィシステムモデリングの始まりをどこ におくかは少しばかりむずかしい.ファジィ理論に基 づくシステム解析やモデル構築の試みはZadeh [115] (68年) にまで遡りうる。だが，ファジィ理論（論理） によるシステムのモデリングということになると, Tong [90）（78年）に始まるとみなせるだろう。この直後に 
Gaines [27］（79年)がある.Takagi and Sugeno［85] とその後継論文,さらには Sugeno and Yasukawa [83] が続き，1つの分野として確立した。

92年には, Horikawa et al. [32］によるファジィニ ューラルネットワークによる解法も加わった。こうし た流れを表 1 に示す。

表 1 年譜

\begin{tabular}{|c|c|}
\hline 年: & 事 柄 \\
\hline 68 & Zadeh [115] \\
\hline 76 & $\begin{array}{l}\text { Jain [34] (ファジィシステム) } \\
\text { Wenstøp [101] (諳棓モデル) }\end{array}$ \\
\hline 78 & Tong [89] (ファジィシステム) \\
\hline 79 & Kickert [40]（語モデル） \\
\hline $78-80$ & Tong [90、91] (ファジィモデル) \\
\hline $81-84$ & $\begin{array}{l}\text { Pedrycz and Czogała [15、70、71、72] } \\
\text { (ファジイ関保システム) }\end{array}$ \\
\hline 85 & Takagi and Sugeno [85] (TSK モデル) \\
\hline $86-88$ & Sugeno and Kang $[80 、 81]$ (TSK モデル) \\
\hline $87-89$ & Xu et al. [105、104]（ファジィ関係システム) \\
\hline 91 & Sugeno and Tanaka [82] (TSK モデル) \\
\hline 92 & Horikawa et al. [32] (FNN) \\
\hline 93 & $\begin{array}{l}\text { Yager et al. [109] (TSK モデル) } \\
\text { Sugeno and Yasukawa [83] (SY モデル) }\end{array}$ \\
\hline 95 & Lin et al. [54] (FNN) \\
\hline $95-96$ & Wang et al. [96、97、98] (TSK モデル) \\
\hline 97 & $\begin{array}{l}\text { Kim et al. [42] (TSK モデル) } \\
\text { Joo et al. [36] (その他のモデル) }\end{array}$ \\
\hline 98 & $\begin{array}{l}\text { Emami et al. [19] (ETG モデル) } \\
\text { Delgado et al. [16] (その他のモデル) }\end{array}$ \\
\hline
\end{tabular}

\section{本稿の構成}

本稿は 4 部からなる。第 I 部はシステムからファジ イシステムモデリングまでの一般的な解説にあてる。 第II部で，ファジィシステムモデリングの問題を詳し く述へ，問題の定式化, 解法の概略, システムの検証 などについて解説する，第III部で主要な解法を紹介寸 る. Tongのファジィモデリング, Pedrycz らのファジ 関係システム, Sugeno を中心とするTSK モデル, SY モデル, さらにETG モデルやFNN（ファジィニ ユーラルネット）による手法などを紹介する，第IV部 を、ファジィクラスタリングや非ファジィ化法などフ アジィシステムモデリングに関連する数々の技法の紹 介にあてる。

\section{1 概 説}

ファジィシステムモデリングという表現はどちらか といえば新しい，ファジィシステムモデリングに至る 諸概念：システム, システム解析, ファジイシステム, ファジィモデリングなどを文献によって略述する，異 なった語が同じ意味で，また同じ語が異なった意味で 用いられたりする。

\section{2 システム}

1950-60年代に始まったシステムに関する研究を支え， 促したのは，オペレーションズ・リサーチ (OR) とコ ンピュータの発達である.この当時, システム解析に 関する書籍が少なからず刊行された。そうした 1 冊で ある McMillan et al. [59] のシステム解析についての 解説は分かりやすい.特に第 1 章(システムとモデル), 第 2 章（シミュレーション）は70年代初頭の研究者の システム解析に対する理解のさまを見ることができる. 日本語では西川ら [64］がある。

以下の定義は両書による.

要素の集合と要素間の関係を合わせた全体をシステ ム system といい, システム自体を記述すること，ある いはシステムの挙動を説明し, 未来のシステムの挙動 を予測することをシステム解析 analysis という (McMillan ら).

モデル model とは, システムの解析者による記述 (McMillan ら), あるいは, 対象とする実体システム の変数間の関係を適切なフィル夕を通して適当な構造 へ写した写体である(西川ら)。そして, システムの構 成や挙動を説明する適切な数学的・物理的な形式など によって実体システムを要約し，その本質的部分を表 現する方法をモデル化 modeling という（西川ら）。そ のうえで西川らは「この写体から得られる情報は, 对 象である実体システムのもつ情報として解釈可能でな ければならない.」と述べている。

シミュレーション simulationの応用には，1）シス テムのデザイン，2）システムの挙動の記述があり， McMillan らは「解析者は, 自分のよく知らないシステ ム自体や，システムの挙動を説明するシステムの構造 についての仮説の検証に, シミュレーションを用いる. 現実のシステムはしばしば‘ブラック・ボックス’とみ なされる．その中身はシステム入力と出力を観察する ことで記述できるものと考えられる。…との理論は現 実のシステムの出力 $y_{1}, \ldots, y_{n}$ とモデルからの出力 $z_{1}, \ldots$, $z_{n}$ を比較することで検証される.」と述べている。

Pedrycz [75] は「シミュレーションは科学の第 3 の 
パラダイムになりつつある」という K. Wilsonの言を 引用している。

どのように出力が得られるかについて具体的な説明 ないし記述なしでシステムが構築される。これをブラ ック・ボックス black box 仮説という。ブラック・ボ ックスは理論でもモデルでもない（McMillanら）。

\section{3 ファジィシステム}

ファジィシステムとは,「情報の少なくとも一部がフ アジィであるシステム」(Jain [34]，76年)である.(入 出力）変量がファジィ (Jain [34]), 入力 (コマンド) と入出力関係, したがって状態や出力もファジィ (Tong [89]）などがある。ささらには，入力空間から出力空間 への 'if-then' (ファジィ) ルールの集まりもファジィ システムとよばれる (Kosoko [46]).

ところで，ファジィシステムに関して特徵的なこと は，現実の「実体システム」は如何に複雑，あるいは 如何にあいまいでも，それ自体にファジィ性はない， ということである。ファジィ性が加わるのは寒体シス テムを記述ないし解秎する段階である。つまり，ファ ジィシステムは常にファジィモデルなのである(例え ば，田中 [86] の書名は「あいまいさを含む実体シス テムのモデリング」の謂いである).

ファジィシステムがファジィ制御に対して果たした 役割を論じたVerbruggen et al. [95］がある.

\section{数学的ファジィシステム}

一般にシステムは，現実の中に存在する「実体シス テム」，それを写しとった「(モデルとしての) システ ム」,さらにそれを抽象化 (数学化) した「数学的シス テム」とに分けられる。こうした事情はファジィシス テムでも同じである。ここで最後の数学的ファジィシ ステムについて簡単に考察する.

数学的ファジイシステムの多くは関係方程式で記述 され，その構造は（少なくとも数学的には）完全に定 まる。ファジィ線形システム (Friedman et al. [25], 変数がファジィ, 係数行列はクリスプ) や動的ファジ イシステム (Kurano and Yoshida et al. [50, 113], 関係行列がファジィ)，その他がある。

数学的ファジィシステムには，数学の中だけで閉じ たもの（上記の例）もあり，実体システムの解析にも 積極的に関与する開いたものもある. Pedrycz（and Czogała) [15，70，71，72，73] は後者の例である.

\section{ファシィ動的システム}

（ファジィ）システムには, 時間に依存しない静的 システムと時間に依存する動的 dynamic システムとが
存在する.

ファジィ動的システムを定義するやり方には，クリ スプな動的システムのファジィ化とファジィ関係行列 による定義という 2つがある. Kloeden [43] は前者で, そのシステムは連続な関数 (ファジィ集合) $(x, t) て ゙$

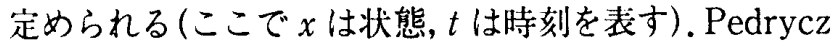
[71] は後者で, (不連続な時刻 $t$ で表される) 1 次のフ アジィ動的システムを

$$
x_{t+1}=u_{t} \circ x_{t} \circ R
$$

で定義した。ここで， $x_{t}, x_{t+1}$ は状態， $u_{t}$ は制御で，フ アジィ性は $R$ に含まれる。

\section{4 ファジィシステムモデリング}

ファジィシステムモデリングという表現はどちらか といえば新しく，必ずしも定着してはいない，初めて 文献に現れたのは，確認できたかぎりでは，Yager［106] （94年）である. Gaines [27]（79年）は，「非決定的 なシステムの構造を，その挙動から導く」という作業 を“同定”と名づけているが，間違いなくファジィシス テムの ‘モデリング’の喨矢である.

\section{ファジィモデル}

Zadeh [116] は（実体）システムを機械的システム と人間的システムに分け，後者をより複雑としている。 「こうした現実の複雑システム（過程）を解析するに はモデル化が必要である.」と分析した。

Tong [90] は「モデルが真の過程 processのシミュ レーションや制御システムの構築に使えるからである.」 と説くが，同時に「複雑過程はしばしば高度に非線形 であり，非常に多くの変数を含んでいるために，同定 するのはきわめて困難である．その基礎となる数学的 構造は見出しがたく，過程の知識は言語的にしか表現 できない場合がしばしばある.」と述べている，彼はフ アジィモデルを゙構造の不正確さ imprecisionをあつか う道具’と規定したうえで,ファジィモデル $M$ を, $A$ を 有限個のファジィ含意（ルール）によって（過去の）

入力と出力から (未来の) 出力を決定するアルゴリズ 厶, $U, S, F$ をそれぞれ入力空間, 出力空間, およU゙ これらの空間の初期状態の集合として, $M=M(A, U$,

$S, F)$ と定義した。

言語によって表現されたモデルは,言語 verbal モデ ル (Wenstøp [101]), linguistic モデル(Kickert [40]) などとよばれる。詳しくいうと，「言語 linguistic 記述 に基づくシステムモデル」(Sugeno and Yasukawa [83])である.また,「データ構造のファジィ解釈」(Bezdek [10]）という意味でファジィモデルともよばれる. 


\section{ファジィデリング}

Sugeno and Yasukawa [83]によれば, ファジィ モデリングはZadeh [115] にまで遡るという。

ファジィモデリングの定義をあげると：「一種のモデ リング手法」(Sugeno and Tanaka [82])；「過程の データのファジィモデルへの転換」(Tong [90])；「未 知の対象から得られた入出力データから，その対象の モデルをファジィルールを用いて記述すること」(古橋, [60], p.267)；「ファジィ集合の方法論を用いたモデリ ング」(Pedrycz [75])；あるいは「ファジィ制御のた めの数学的モデル」(Lygeros [55]) という理解や「フ アジィ論理に基づく記述言語を用いたシステムモデル 構築の手法」という定義もある(Sugeno and Yasukawa $[83])$.

\section{ファジィシステムモデリング}

ファジィシステムモデリングは，ふつうには，ファ ジィモデリングとほほ同義に理解されている。この意 味でのファジィシステムモデリングの始まりはTong [90］ である。

しかし, 現在, ‘ファジィシステムモデリングはもう 少し限定した意味で理解されている。すなわち，

1）複雑なシステムをファジィ含意を用いて表す

2)（本質的に）非線形システムである

の 2 点を特徴とする (Sugeno and Kang [80]，ただ しこの論文ではまだ「ファジィモデリング」である).

Horikawa et al. [32] はファジイ推論規則を用いて システムの特徵を記述する手法と定義し, Emami et al. [19］は，言語変数を用いること, IF-THEN ファジィ ルールによる变数間の関係の記述, ファジィ推論 reasoning アルゴリズムによる定式化の 3 つを特徴としてあげ た.

こういう理解でのファジィシステムモデリングは Takagi and Sugeno [85] に始まる. Sugeno and Kang $[80 ， 81]$ がこれに次ぎ(著者たちの頭文学をと って TSK モデルと呼ばれる)，さらにSugeno and Yasukawa [83] (SYモデル) がある.

\section{質的モデリング}

質的モデリングは Sugeno and Yasukawa [83]に よって導入された. システムの挙動を, 数值によって でなく，自然言語によって記述する，より一般的なつ アジィモデルである，と説明される。彼らはファジィ モデリングの究極の目的は質的モデリングにあると説 く．モデリング手法は，(数值的)ファジィモデリング と言語的近似の 2 段階に分かれる。

しかしながら，その後質的モデリングに関する研究 はほとんどみられない.質的モデリングについては Sugeno and Yasukawa [83］に直接あたっていただきたい。

\section{II 問 題}

\section{5 何を? どのように?}

ファジィシステムモデリングの究極の目標は，当然 システムの構造を明らかにすることであるが，現実に はきわめて困難である。 そこで，実際の出力 $y$ に可能

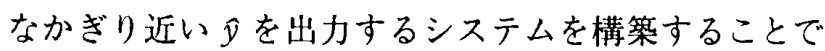
よしとする考え方と，「対象の構造を発見することを重 視する」という考え方とがでてくる（中森ら［62]）．

以下, 本稿であつかうのは多入力 1 出力 multi-inputsingle-output (MISO) システムである. Emami et al. [19］が指摘するようにもし出力がたがいに独立なら ば, 多入力多出力 multi-input-multi-output (MIMO) システムは MISO に帰着されること，また，実際の多 くのシステムでは出力はたがいにほほ独立と見なせる ことなどから，多入力 1 出力と仮定できる。

\section{1 システムの環境}

実際のシステムは，それぞれの構造をもち，その構 造は，システムの決定に何らかの影響を与える。

\section{システムモデリングの目的}

1. 制御：入一出力関係によって, 出力を制御する.

2. 予测：未来の出力を予測する。

\section{静的システムと動的システム}

1. 静的なシステム：時間に関係のないシステム。

2. 動的なシステム：時間に関係したシステム。

(Box and Jenkinsのガス炉がその例).

動的なステムでは，過去・現在のシステムの状態も 未来の入力になる. システムの状態はその時点の出力 によって（間接的に）推測される。

\section{事前知䪭の存在}

1. システムの構造について何らかの知識をもって いる.

2. システムの構造について何の知識ももたない. 事前知識のない場合，システムの同定は入出力のみ によってなされる.

\section{2 基本モデル}

基本モデルは Sugeno and Yasukawa [83］に準拠 すれば，次のように表される。

$R^{i}$ : If $x_{1}$ is $A_{1}^{i}$ and $\cdots$ and $x_{n}$ is $A_{n}^{i}$ then $y$ is $C_{i}(x), i=1, \ldots, m$, 
ここで $x=\left(x_{1}, \ldots, x_{n}\right)$ は入力変数, $A_{1}^{i}, \ldots, A_{n}^{i}$ はファ ジィ集合, $C_{i}(x)$ は結論部 ( $x$ の関数または言語変数 $)$ である。

$C_{i}(x)$ によって, 言語モデル(YS モデル, ETG モデ ル)，あるいは数值モデル（TSK モデル）が得られる。

(1) 言語モデル： $C_{i}(x)=B_{i}$.

(2) 数值モデル：

(2a) 数值（線形）モデル： $C_{i}(x)=a_{0}^{i}+a_{1}^{i} x_{1}+\cdots+a_{n}^{i} x_{n}$.

(2b) 数值（非線形）モデル： $C_{i}(x)=f_{i}\left(x_{1}, \ldots, x_{n}\right)$.

\section{入出カモデルの歷史}

（1）言語モデルの起源はZadeh [115]（68年）にま で遡りこれに Mamdani が続く.システムモデルにお いては, Tong [90] (78年) に始まり，Czogała and Petrycz [15] (81年), Pedrycz [72] (84年), Sugeno and Yasukawa [83]（93年）などが続く.

(2) 数值 (線形) モデルは Takagi and Sugeno [85] （85年）に始まり，Sugeno and Tanaka [82] (91年) が続く.

（3）数值（非線形）モデルは Yager et al. [109]（93 年)に始まる。

\section{3 標準的な決定手順}

与えられた入力に対して，1）各ルールの発火の度 合いを計算し，2）ルールごとの出力を求め，3）最 後にそれらを統合して推論出力とする，具体的なアル ゴリズムは以下のとおりである.（Emami et al. [19] の推論アルゴリズムはこれと萁なる、第III部で解説す る.)

\section{出力推論アルゴリズム}

ステップ1）与えられた入力 $x^{0}=\left(x_{1}^{0}, \ldots, x_{n}^{0}\right)$ に対し て，第 $i$ ルルの前件部との一致度 $w_{i}$ を

$$
w^{i}=w\left(A_{1}^{i}\left(x_{1}^{0}\right), \ldots, A_{n}^{i}\left(x_{n}^{0}\right)\right)
$$

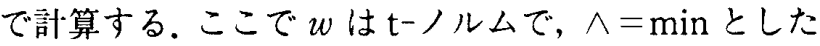
のが Takagi and Sugeno [85] 以下, Wang et al. [96, 97, 98], Kim et al. [42] などで, Reichenbach (代数) 積×としたのが Sugeno and Kang [80], Schweizer and Sklarのパラメトリック $\mathrm{t}$ ノノルムを用 いたのは Emami et al. [19] である.

ステップ 2 ) 結論部を計算する。

数値モデルでは： $y^{i}=f_{i}\left(x^{0}\right)$

言語モデルでは： $y^{i}=b^{i}=\operatorname{Defuzz}\left(B^{i}\right)$

で計算する。ここで, Defuzz は非ファジィ化である.

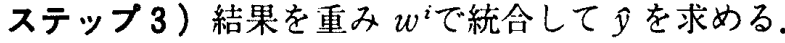

$$
\hat{y}=\sum_{i=1}^{m} w^{i} y^{i} / \sum_{i=1}^{m} w^{i}
$$

注）ステップ 2 の結果，言語モデルは実際には，数值 モデルの特別な形

If $x_{1}$ is $A_{1}$ and $\cdots$ and $x_{n}$ is $A_{n}$ then $y=b$

に帰着する。ファジィ集合 $B_{i}$ はシステム同定において のみ用いられる。

\section{6 システム同定}

\section{システム同定の目標}

ファジィシステムモデリングの目標は，どのような 機構で出力が得られるかを説明することである。この 目標の達成は以下の手順による。

(1) 入力変数を特定する,

(2) 入力から出力が得られる機構を明らかにする.

\section{システム決定の手法}

Kim et al. [42]によれば，システムの決定には幾多 の手法があるという。彼らはそれを次のように分類し た. パタン認識 (Sugeno and Yasukawa [83]), シ ステムプログラミング理論 (Sugeno and Kang [80, 81] や Sugeno and Tanaka [82]，ファジィ参照集合 を用いる (Pedrycz [72])，およびニューラル・ネット 手法 (Tong [90], Horikawa et al. [32], Lin et al. [54]，およびXu et al. [105]）などである.

\section{1 システム同定の手順}

Sugeno and Yasukawa [83] はファジィシステム 同定の手順を整理して表 2 とした。

表 2 システム同定

\begin{tabular}{l|l}
\hline 構造同定 I & $\begin{array}{l}\mathrm{a}: \text { 入力候補 } \\
\mathrm{b}: \text { 入力変数 }\end{array}$ \\
\hline 構造同定II & $\mathrm{a}:$ ルール数 \\
& $\mathrm{b}:$ 入力空閒の分割 \\
\hline パラメータ同定 & \\
\hline
\end{tabular}

彼らによれば，構造同定 I 对 II 对パラメータ同定の 重要性の比率は100：10：1ぐらいであろうとのことで ある。

\section{［1］構造同定 I：入力变数の決定}

システムモデリングでは，出力を（真に）決定して いるのはどの入力変数であるかは必ずしも自明でない。 
その結果, 入力变数の決定は次の 2 つの段階からなる.

段階 I a）入力变数の候補の決定 : Sugeno and Yasukawaは, 「無限に多くの入力変数の候補があり，それ をある数に限定しなければならない」わけだが，「無限 から有限の選択であるが故に…システマティックな解 法はない.」よって「我々は経験や常識に基づきヒュー リスティックな方法をとらさるをえない.」と説く。そ のうえで「入力候補が決定されれば，問題は解けたも 同然である.」という。

しかし，入力変数が所与であることも多く，この段 階は省略できる。

段階Ｉb）入力变数の選定: Sugeno and Yasukawa はいう：「この段階は, 有限の候補の中から有限の変 数を選びだすのだから，システマティックに解くこと ができる.」 Sugeno and Kang [80] は次のような方 法を示す。

1）システムの物理的性質および経験的知識を用い る.

2 ）最も大きな偏相関係数をもつ変数を選ぶ.

3 ）最小の PSS（子測 2 乗和 prediction sum of square）をもつ变数を選ぶ.

具体的な解法は Emami et al. [19] でによって整理 されている(第IV部12節参照).

\section{［2］構造同定II：入出力関係の決定}

“構造同定 II”はシステム同定の幹の部分である。 入出力関係の決定とは, 可能なかぎ簡単な形で入力 と出力の関係を記述することである。標準的なファジ イシステムモデリングの手法は，入力空間を分割し， 各小領域ごとに入出力関係を簡単な'関係ルール’すな わち 'If-then’においてルールで記述する. 入出力関係 はモデルの構造で決まる。

「幹の部分である」ためいくつかの同定手順がある。 その大略を示す。

Sugeno and Kang [81] (TSK model):

II a）前提部の構造同定

・前提部で必要な変数の発見

・適切なファジィ分割

IIb）結論部の構造同定

・結論部で必要な変数の発見

Sugeno and Yasukawa [83] (YS model) :

II a）入出力関係ルール数の決定

IIb）入力空間の分割

FCM 法（後述・第IV部）によればこれらは同時に決 定されるので，実際には，IIa）とIIb）は分けられな
い.

Emami et al. [19] (ETG model) :

IIa）ルール生成

IIb）入力とメンバーシップの選択

\section{[3] パラメータ同定}

パラメータの同定は

a）前提部のパラメータ同定：含意 (ルール)の前提

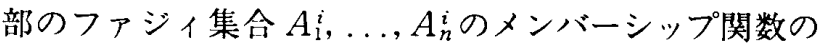
決定.

b）結論部のパラメータの同定：

・TSK モデルでは係数 $a_{0}^{i}, a_{1}^{i}, \ldots, a_{n}^{i}$

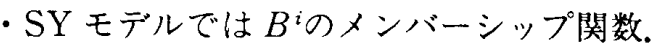

また，Emami et al. [19] はこれらと違った同定法 を用いている。

\section{2 システムの検証}

\subsection{1 システムの評価指標}

検証のための指標にはいくつかあるが，最もよく用 いられているのが平均 2 乗誤差（MSE）である。

平均 2 乗誤差 (MSE)

$$
\mathrm{PI}=\frac{1}{n} \sum_{i=1}^{n}\left(y_{i}-\hat{y}_{i}\right)^{2} .
$$

この指標は $J$ とも書かれる (Sugeno and Tanaka [82, p.327])。なお，いささか奇妙なことだが, Sugeno and Tanaka [82］では，同じ $J$ が別の箇所（p.330） では別の指標を表す記号として用いられている。

Delgado and Gómez-Skalmeta et al. [16] は $E=$ $\sqrt{\mathrm{PI}}$ を用いた。

評価指標 (近藤 $[45]$ ).

$$
J=\frac{1}{n} \sum_{i=1}^{n} \frac{\left|y_{i}-\hat{y}_{i}\right|}{y_{i}} \times 100(\%) .
$$

近藤 [45］は彼の指標をモデルの精度と呼んでいる． また，この指標は $\mathrm{AC}$ (または $\left.\mathrm{AC}_{\text {model }}\right)$ とも書かれる (Takagi and Sugeno [85]).

\section{光の他の指標}

- $E=\sum\left|y_{i}-\hat{y}_{i}\right| / \sum y_{i} \quad$ (Sugeno and Kang [80]) $\cdot \Delta=\sum\left(y_{i}-\hat{y}_{i}\right)^{2} / \sum y_{i}^{2} \quad$ (Sugeno and Kang [81]) - $\rho(y, \hat{y})$ (Pedrycs [71])

- $\mathrm{PI}=\sqrt{\sum\left(y_{i}-\hat{y}_{i}\right)^{2}} / \sum\left|\hat{y}_{i}\right| \quad$ (Lin et al. [54]) 


\section{2 .2 システムの検証例}

\section{Box and Jenkins のガス炉}

この例はシステム同定の標準的な検証データとして 知られている. 296コの入出力データからなる. 入力は ガス流率で, 出力は排気ガス中の $\mathrm{CO}_{2}$ 濃度である.

検証結果は本稿では以下の形式で表記する。

\begin{tabular}{l|ccc}
\hline Model & PI & PV & FI \\
\hline
\end{tabular}

ここで, PI は評価指標；PV は前件部変数の数, FI は ルール数を，それぞれ表す。

\section{Sugeno and Yasukawa [83] の非線形関数}

$$
y=\left(1+x_{1}^{-2}+x_{2}^{-1.5}\right)^{2}, \quad 1 \leq x_{1}, x_{2} \leq 5
$$

からの50個の入出力データ.これにタミー入力变数 $x_{3}$, 神を加えたものをデータとする.

\section{光の他の検証例}

・近藤 [45] の非線形関数.

$$
y=\left(1+x_{1}^{0.5}+x_{2}^{-1}+x_{3}^{-1.5}\right)^{2}, \quad 1 \leq x_{1}, x_{2}, x_{3} \leq 5
$$

\section{III 解 法}

ファジィシステムモデリングの解法については第 I 部表 1 の年譜をご覧いただきたい。ファジイ関係モデ ルとしての解法は Tong（78年-80年）と Pedrycz（81 年-84年),ファジィ推論によるものとして TSK モデル (85年-88年) および SY モデル (93年)，ETG モデル などがある。さらに FNN による解法もある。

\section{7 ファジィ関係モデル}

ファジィモデリングは Tong [90, 91] (78年, 80年) に始まる。このときは制御のためのモデリングである. これに, Pedrycz [71, 72] が続く.

\subsection{Tong}

Tongは [89] (78年) でファジィモデリングの設計 法を提案し，[91］（80年）でその評価を行った。ただ し，彼にはそのまえにファジィ(制御) システムを導 入し，その解析と制御について論じた [89] がある. Joo et al. [36] は「…この手法は高次元に拡張するこ とが困難である.」と注釈する。

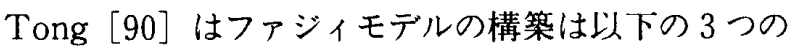
段階からなるという：1）モデルのクラスの定義，2） ルールの同定，3）モデルの質の評価.

モデルのクラスの定辣とは，事前の知識の定式化の
ことで，主観的なものである．それには，ファジィ変 動空間の量子化, 初期ファジィ集合の定義, 入力・出 力として表されるモデル構造の選択などがある.

入力变数の特定は，1つ1つの入力変数と出力との 相関を四示し，その困の視認による。

ルールの同定について，a）質的な知識の利用，b) プ ロセスで成り立つ数学的関係の（ファジィ的）解釈, c) 入出力デー夕の利用などがある, とし，a）とb)は工 学的な感覚によるもの,c)は論理的検查 examination (LE) であると説明している.

彼は, 2 つの非ファジィ化法, 重心法 COA (center of area）と最大平均法 MOM (mean of maximum) による結果を比較し，全ての場合に重心法が勝るとい う結論を得た。1例を下の結果に示す。

最後にモデルの評価について 4 つの指標を提案した：

1) 複雑性 complexity (関係の数)，2）平均 2 乗誤差,

3 ) dicretization, 4 ) 鋭敏性 sharpness.

[91] ではファジィモデルの評洒についてさらに詳し く論じた。

\section{検钲例}

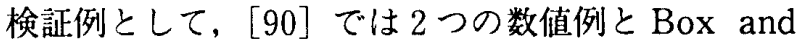
Jenkins のガス炉問題を，[91] では Box and Jenkins のガス炉問題 ([90] と重複) と河川の水質問題を取り 扱った。

例 1 Box and Jenkins のガス炉

この例では, 上の関係において, $x_{1}=u(t-4), x_{2}=$ $y(t-1)$ および $y=y(t)$ とおき, $(u(t-4), y(t-1))$ と $y(t)$ との関係を遷移表（行列） $R$ によって与之た．例 えば,

If $u(t-4)$ is $N Q 1 \& y(t-1)$ is $C 3$ then $y(t)$ is $C 4$

とする.

入力 $(\tilde{u}(t-4), \tilde{y}(t-1))$ に対して,

$$
\tilde{y}^{*}(t)=(\tilde{u}(t-4), \quad \tilde{y}(t-1)) \circ R,
$$

によって $\tilde{y}^{*}(t)$ を計算し,これを $y^{*}(t)=\operatorname{Defuzz}\left[\tilde{y}^{*}(t)\right]$ によって非ファジィ化して $y^{*}(t)$ を得る。ここで, $\tilde{u} お ~$

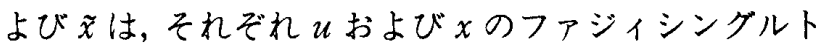
ンを表す。

\section{- 結果}

\begin{tabular}{c|ccc}
\hline Model & PI & PV & FI \\
\hline Tong & 2.653 & 2 & 11 \\
\hline Tong & 0.797 & 2 & 13 \\
\hline Tong (COA) & 0.469 & 2 & 19 \\
\hline Tong (MOM) & 0.971 & 2 & 19 \\
\hline
\end{tabular}


例 2 河川の水質問題

この例は 5 入力・ 2 出力問題である.

入力：上流 $\mathrm{BOD}$, 上流 $\mathrm{DO}$, 流水量, 水温, 日照時 間

出力: 下流 BOD, 下流 DO.

BOD およびDOはそれぞれ生物的酸素需要量および融 解酸素量を表す．結果は原論文にあたられたい。この 問題は私には面白く思われたが，継承者は今のところ ないようである。

\subsection{Pedrycz and Czogała}

Pedryczは（Czogała とともに）離散時間のファジ イ関係モデルを開発した。彼は有限空間 $X=\left\{x_{1}, \ldots\right.$, $\left.x_{n}\right\}$ と有限制御 (入力) 空間 $U=\left\{u_{1}, \ldots, u_{m}\right\}$ をあ つかった。

一連の論文は以下のように整理できる.関係を $R$ で 表す. $X_{k}, X_{k+1}$ は時刻 $t=k, k+1$ におけるファジィ集 合, $U_{k}$ おび $U_{k-\tau}$ はそれぞれ時刻 $t=k$ および $t=k-$ てにおける制御（入力）とする.

[1] Czogała and Pedrycz [15]（81年）:

$$
X_{k+1}=X_{k} \circ R \text {, }
$$

[2] Pedrycz [70] (81年)，［71］(83年)：

$$
X_{k+1}=X_{k} \circ U_{k} \circ R \text {, }
$$

[3] Pedrycz [72] (84年):

$$
X_{k+1}=U_{k-\tau} \circ X_{k} \circ R \text {. }
$$

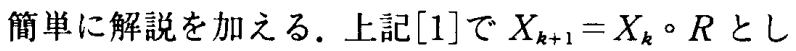
て出発したPedrycz は [70] でシステムに制御項 $U_{k}$ を 新たに加え，[2]とし，同時に，彼はプロセスの未来の 状態 $X_{k+m}$ 予測の問題に踏みだした。ただし, 制御量は $U_{k}=U$ (一定) とする.

Pedryczは参照ファジィ集合(Willaeys et al. [102] 参照) を導入し,ファジィ弁別 incretization (chopping) 法によってシステム同定を行った。これはデー夕空間 を有限集合（参照ファジィ集合）に落として解析する 方法である（第IV部，第12節参照.)

引き続いて [72] で, Pedryczはファジィ関係シス テムを概括し，特に

1) ファジィ関係システム（ファジィ関係方程式で 記述される)

2) ファジィ関数システム（ファジィ化されな線形 システム)

という2つのクラスについて広く論じた。 また， [72] では制御入力を時刻 $t=k-\tau$ のものとした。

\section{同定アルゴリズム}

1.ファジィあるいは非ファジィの入出力デー夕を
集め，必要な空間を設定する。

2.クラスタリング; 参照ファジィ集合または基本 的ファジィ集合を定義する.

3.デー夕を基本的ファジィ集合によって表現する。

4.モデルの構造を決定する。

5 .ファジィ関係 $R$ を計算する。

6.モデルを検証する。

検証例 Box-Jenkinsのガス炉

\begin{tabular}{c|c}
\hline 参照ファジィ集合数 & $\mathrm{PI}$ \\
\hline 5 & 0.776 \\
\hline 7 & 0.478 \\
\hline 9 & 0.320 \\
\hline
\end{tabular}

\subsection{Xu et al. ([105]，87年；[104]，89年)}

Pedryczの後を継いで，その手法を自己学習法によ って改善したXu et al.の 2 編の論文 $[105,104]$ があ る.

検証例 Box-Jenkins ガス炉。

$$
\begin{array}{c|c}
\hline \text { Type } & \text { PI } \\
\hline \text { 非修正 } & 0.456 \\
\hline \text { 修正 } & 0.328 \\
\hline \text { 参照ファジィ集合数 }=5
\end{array}
$$

このほか, 液体化接触分解装置の検証例がある.

\section{TSK モデル}

新しいモデルが Takagi and Sugeno [85] および Sugeno and Kang [80, 81] によって提案された。 のモデルは彼らの䫓文字をとって TSK モデルとして知 られている(中森ら [61］は高木・菅野モデルという).

一連の論文で Sugeno([85] で Takagi と, [80,81] でKangとともに）ファジィモデリングとそのモデル によるファジィ制御の設計について調へた。

このモデルの特徴は，入出力関係にある.すなわち， 結論部を入力变数の線形関数：

$R^{i}$. If $x_{1}$ is $A_{1}^{i}$ and $\cdots$ and $x_{n}$ is $A_{n}^{i}$ then $y^{i}=a_{0}^{i}+a_{1}^{i} x_{1}+\cdots+a_{n}^{i} x_{n}, \quad i=1, \ldots, m$ によって表している点にある.ここで, $m$ はルール数, $n$ はデータの次元, $x=\left(x_{1}, \ldots, x_{n}\right)$ は入力変数である.

このモデル(あるいはアイディア)は Takagi-SugenoKang [85，80，81] によって与えられた。その後多く の継承的研究: Sugeno and Tanaka [82], Yager et al. [109] (構造とパラメータ同定の統一的手法), Wang et al. [96, 97，98]（ファジィ弁別法）などがある. 


\subsection{Takagi-Sugeno-Kang}

Sugeno and Kang は [80] の中で, ファジィ制御の 設計に関して 3 つの手法があると説く：

1）人間のオペレータの経験あるいは技術者の知識 に基づく方法。

2）人間のオペレータの制御行動のファジィモデル 化による方法。

3 ) プロセスのファジィモデルに基づく方法.

当初は, Sugenoは（Takagi とともに [85]で）フ アジィ制御のためのシステムの同定を試みたが, 後に (Kang とともに $[80,81]$ で)方向をファジィシステ ム構築に転じた。

モデル 3 編を通じてモデルは当然 TSK モデルである. だが，2，3の小さな変更がなされている.

まず一致度（発火の高さ）はSugeno and Takagi [85]では,

$$
w^{i}=A_{1}^{i}(x) \wedge \cdots \wedge A_{n}^{i}(x)
$$

だが, Sugeno and Kang [80, 81] では,

$$
w^{i}=A_{1}^{i}(x) \times \cdots \times A_{n}^{i}(x)
$$

である、次に，ファジィ集合 (メンバーシップ関数) の形が異なる. Sugeno and Takagi［85］では図 1 に 示すファジィ集合を用いている。それに対して, Sugeno and Kang [80,81] では通常の台形型メンバーシップ 関数である.

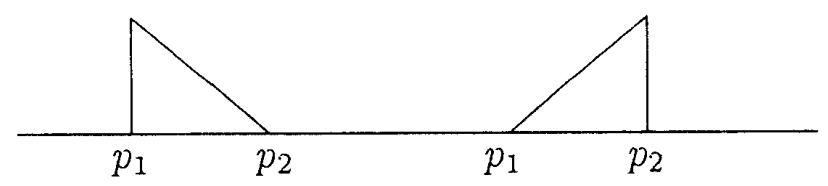

図 1 半三角型メンバーシップ関数

ファジィモデリング 彼らはモデル構築は1）システ ムモデルを表現する数学的道具，と 2 ) 同定法の 20 によって特徴づけられるという。

表 3 同定の機構

\begin{tabular}{l|l}
\hline 数学的道具 & ファジィ含意 \\
\hline \multirow{2}{*}{ 同定 } & 構造同定 \\
\cline { 2 - 2 } & パラメータ同定 \\
\hline
\end{tabular}

\section{アルゴリズムの概略}

「前提部変数の組み合わせの決定」に始まり，「前提 部パラメータの決定」と「結論部パラメータの決定」 をくり返し，その後「前提部变数の組み合わせの決定」 に戻り，全作業をくり返す。

\section{Sugeno らの同定作業の一筧}

Sugeno らは同定作業を［85］と［81］で分散して説 明している。ここでそれを整理して一覧表の形で提示 しておく(表 4$)$.

表 4 Takagi-Sugeno-Kang の同定作業

\begin{tabular}{l|l}
\hline \multicolumn{2}{l}{ 構造同定 } \\
\hline 前提部構造同定 & $\mathrm{S}-\mathrm{K}[81 、 \mathrm{p} .20]$ \\
\hline 結論部構造同定 & $\mathrm{S}-\mathrm{K}[81 、 \mathrm{p} .30]$ \\
\hline パラメータ同定 & \multicolumn{2}{|l}{ パ } \\
\hline 前提部変数の選択 & $\mathrm{T}-\mathrm{S}[85 、 \mathrm{p} .121]$ \\
\hline \multirow{2}{*}{ 前提部パラメータ同定 } & $\mathrm{T}-\mathrm{S}[85 、 \mathrm{p} .120]$ \\
\cline { 2 - 2 } & $\mathrm{S}-\mathrm{K}[81 、 \mathrm{p} .26]$ \\
\hline 結論部パラメータ同定 & $\mathrm{T}-\mathrm{S}[85 、 \mathrm{p} .119]$ \\
\hline
\end{tabular}

[1] Takagi and Sugeno ([85]，85年)

この論文の目的は, 数学的道具を提示し, システム のファジィモデルを構築することである.

彼らは，まず a)含意の定式化，b) 推論 reasoning の アルゴリズム，c)推論の性質について論じ，ついで同 定のアルゴリズムを与えた.アルゴリズムは表 4 の T -Sで表した部分である。

それぞれの詳細は以下のとおり。

結論部パラメータの同定 は前提部変数とそのパラメ 一タが与えられたという条件のもとで行われる。パラ メータ (ベクトル) は定常状態 Kalmanフィルタによ つて計算される。

前提部パラメータの同定 は非線形プログラム問題に 帰着する。

前提部变数の選択 は2つの問題からなる．1つは変 数の選択である (これらの変数の空閒が分割される). 他の 1 つは（変数空間の）分割の数である。これらの 探索はヒューリスティックになされる.

\section{検証例}

1. 水浄化のプロセス

この例では，制御が扱われている，すなわち，原水 に加える PACの最適量の決定問題である。

2 . 鋼製造過程の転換炉

この例では，モデリングと制御の両方が扱われてい る.

（1）モデリング：製品におけるマンガン比の増加を 予测する,

（2）制御：加えるべきマンガンの量を決定する. 
[2] Sugeno and Kang ([80]，86年)

この論文は,いわゆる TSK モデルとは別の流れに属 する.ファジィ制御器の設計とそのためのファジィモ デリングを目的とし，1）ファジィ同定の手法，2）フ アジィモデルに基づくファジィ制御設計の手法 とい う2つの手法を示した.

ファジィモデリング構造 (プロセス) 同定の概略 (表 3 ）を与え, 多層焼却炉を例に，2 入力 2 出力のプロ セス設計を詳細に論じている。

[3] Sugeno and Kang ( $[37,81] 87$ 年-88年)

菅野と姜は［37］および［81］において構造同定を 詳細に論じている。[37] で, 近藤 [45]提唱の改良形 GMDH との比較を行った. 近藤の例題をファジィモデ リング手法で同定し，その優秀性を示した。

[81] で Sugeno and Kangは, 構造の検証基準に 基づき，構造同定を論じ，前提部パラメー夕修正のア ルゴリズムを調べている。

前提部構造同定 は入力空間のファジィ分割を見つけ る問題に帰着する。

構造検証の基準 として不偏基準 UC (unbiasedness criterion)を用い，これを最小にする前提構造を選ぶ. そのアルゴリズムは：まず通常の線形モデルを同定し, $\mathrm{UC}$ を計算する（これを $\mathrm{UC}_{[1]}$ と表す）ことから始め， 各変数 $x_{i}$ の領域に分割 (たとえば'small'と 'large'とに)

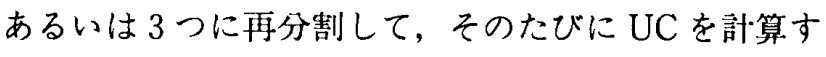
る. 第 $k$ 段階で, UCを最小とするモデル $\mathrm{ST}_{[k]}$ の UC $\left(\mathrm{UC}_{[k]}\right.$ で表す) と前段階の $\mathrm{UC}_{[k-1]}$ とを比較する. 分割 あるいは再分割を, UC が減少しなくなるまでくりかえ 古.

この後に, 前提部パラメータの同定一修正アルゴリズ ムと結論部構造同定が続くが, それらの説明は省略さ れている。

\section{検証例 として近藤 [45］の非線形関数}

$$
y=\left(1+x_{1}^{0.5}+x_{2}^{-1}+x_{3}^{-1.5}\right)^{2}, \quad 1 \leq x_{1}, x_{2}, x_{3} \leq 5
$$

と, Dniepr 川の流水量の予測問題があつかわれている.

\section{[4] Sugeno and Tanaka の方法 ([82]，91年)}

Sugeno and Tanaka [82] の提案した逐次的ファジ イモデリング法は初期モデルから出発して，これに逐 次修正を加えていくというモデリング法である.同定 の機構は表 5 のとおりである.

初期モデル は Sugeno and Kang [81] に従い, オフ ラインモデリング法で同定される.
表 5 同定機構

\begin{tabular}{l|l}
\hline 初期モデル & \\
\hline \multirow{3}{*}{ 逐次同定 } & 監督 supervising レベル \\
\cline { 2 - 2 } & 修正 adjustment レベル \\
\hline
\end{tabular}

\section{逐次同定}

・監督レペル はパラメータ修正の方策を決定する。 与えられた入出力デー夕に対して，パラメータの調整 のしかたのルール FAR (fuzzy adjustment rules) を 決定する．前提部のパラメー夕，あるいは結論部のパ ラメータの修正を必要とする。

・修正レベル 監督レベルで決まった調整をWRLSA (weighed recursive least square algorithm) によっ て行j.

検証例 Box and Jenkins のガス炉

彼らの手法では, Tong [91], Pedrycz [72] や Xu [105，104] に比べ，大きな改善（評洒指標 PI の大幅 な減少が見られる)。ただし，この改善がTSK モデル によるのか，逐次同定によるのか，あるいはその両方 によるのか明らかでない.

\begin{tabular}{c|ccc}
\hline Model & PI & PV & FI \\
\hline ST & 0.068 & 6 & 2 \\
\hline ST' $^{\prime}$ & 0.359 & 2 & 2 \\
\hline
\end{tabular}

このほかに河川流水量の子测がある。

\section{2 その後の展開}

\section{[1] Yager and Filev の方法 ([109]，93年)}

Yager and Filev [109] は構造同定とパラメー夕同 定を同時に行う統一同定法を提唱した。

そのモデルは後件部を $y=f_{i}(x)$ とし,$f_{i}$ が線形, ある いは非線形に応して，QLFM (Quasi-Linear Fuzzy Model)あるいはQNFM (Nonlinear) と名づける.

彼らの手法は，全空間をファジィ領域(凸クラス夕) に分解し，それを各成分に射影して入力空間のファジ イ領域 (cluster-like 領域) $R_{i}$ を定める. また，各ルー ルの発火の高さを標準化 (和=1) したものを確率と解 釈する標本化確率分布 SPD (sampled probability distribution）を導入した，彼らの論文には特に検証例 はない.

なお,この前にQLFM を導入した Filev [22］があ る. 
[2] Wang et al. ([96, 97, 98], 95年-96年)

Wang et al.は一連の論文で前提部同定と結論部同定 を分離する手法を提案した。 [96] で結論部の決定に直 交推定量を用いたが，そのアルゴリズムは Korenberg et al. ('88) および Billins et al. ('88) に基づく（い ずれも末入手). [97] で前提部の決定にファジィ弁別 法を用いた。 ‘前提部の構造’とは入力変数のメンバー シップ関数を意味する。したがって，ルールの数は参 照ファジィ集合の数によって決定される.(ファジィ弁 別法については第IV部を参照.)

彼らの一致の高さは $w_{i}=A_{1}^{i}(x) \wedge \cdots \wedge A_{n}^{i}(x)$ である. 次いで, Wang et al. [98] で, TSK モデルに白色 雑音 (平均 0 の Gaussian 過程 $\xi^{i}$ )を加えたモデルを考 えた。すなわち，後件部

$$
y_{i}=a_{0}^{i}+a_{1}^{i} x_{1}+\cdots+a_{n}^{i} x_{n}+\xi^{i}
$$

とする.結論部の同定に期待値最大化EM (expectationmaximization) アルゴリズムを提案した。

検証例 Box and Jenkinsのガス炉

\begin{tabular}{c|ccc}
\hline Model & PI & PV & FI \\
\hline Wang [96] & 0.066 & 6 & 2 \\
\hline Wang [97] & 0.158 & 2 & 5 \\
\hline Wang [98] & 0.059 & 6 & 2 \\
\hline
\end{tabular}

このほか, Box and jenkinsのバッチ化学プロセス, 重合物のプラント， 2 階微分方程式といった検証例が ある。

[3] Kim らの新アルゴリズム ([42]，97年)

Kim et al. [42] は Takagi and Sugeno [85] のモ デルを基本モデルとして採用し，これに Sugeno and Yasukawa [83］を改良した手法を適用した.

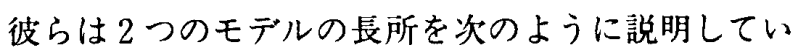
る.まず Takagi and Sugeno モデルは, (1)非線形関 数関係が少数のファジィルールによって表せること, (2)その応用可能性が大きい,の 2 点である. Sugeno and Yasukawa モデルはパラメータ同定アルゴリズムが容 易である。

彼らはこの論文において, FCM 法(ファジィ $c^{- \text {平均 }}$ 法, 超球型クラス夕)に代わる FCRM（ファジィ $c$-回 帰モデル, 超平面型クラスタ) クラスタリング法を提 案した. FCRM 法によって同定過程の簡単化が可能に なると説明している.

彼らの方法では, 表 6 に示す 2 段階のチューニンク が必要である.第 2 段階は勾配降下アルゴリズム gradient descent algorithmである.
表 6 同定法の概略

\begin{tabular}{c|l}
\hline \multirow{2}{*}{ ×ンハーーシップ } & $\begin{array}{l}\text { FCRM クラスタリングよる粗い } \\
\text { coarse チューニンク }\end{array}$ \\
\cline { 2 - 2 } & $\begin{array}{l}\text { GD アルゴリズムによる練かなチュ } \\
\text {-ニンク }\end{array}$ \\
\hline
\end{tabular}

なお本論文の一致度は $w_{i}=A_{1}^{i}(x) \wedge \cdots \wedge A_{n}^{i}(x)$ であ る.

検証例 Box and Jenkinsのガス炉

\begin{tabular}{c|ccc}
\hline Model & PI & PV & FI \\
\hline Kim et al. & 0.055 & 6 & 2 \\
\hline
\end{tabular}

このほか, 非線形システムの検証例がある.

[4] Gomez-Skarmeta and Delgado et al. ([29], 99年)

入力空間 $X^{p}$ と出力空間 $Y$ の積空間 $X^{p} \times Y$ の上の クラスタリングを, Gustafson-Kessel（79年）のアル ゴリズムにより決定し, 入力 $x$ に対する出力 $y$ を定め る.

複数のクラス夕 (ルール) からの出力 $y_{h}$ を $\hat{y} に$ 統合 する3つの方法を比較した。

検証例 Box and Jenkinsのガス炉

\begin{tabular}{c|ccc}
\hline Model & PI & PV & FI \\
\hline Gómez-Skarmeta et al. & 0.157 & 2 & 2 \\
\hline
\end{tabular}

注：Gómez-Skarmeta らは, モデルの評価指標とし て $E=\sqrt{\mathrm{PI}}$ を採用している.ここでは比較のため $E$ を 2 乗したものを示した。

このほか, Sugeno and Yasukawa の非線形システ ムと Zimmermann and Zysno (80年) のデータが検証 例として用いられている。

\section{[5] TSK モデルの逆問題}

領家ら [77］は高木·菅野モデル（彼らはこう呼ぶ） の逆問題を取りあげた。すなわち，与えられたTSK モ デルにおいて, 出力から入力を求めるという問題であ る.

\section{SY モデル}

SY モデルは Sugeno and Yasukawa [83] によって 導入された. 今のところ Emami et al. [19, 20] 以外 にこのモデルの継承者はない。 


\subsection{Sugeno and Yasukawa の質的モデリング（[83], 93年)}

質的モデリングの基本モデルは以下のとおり。デー 夕 $x=\left(x_{1}, \ldots, x_{n}\right)$ に対して, $i=1, \ldots, m$ について, 各ルールは

$R^{i}$. If $x_{1}$ is $A_{1}^{i}$ and $\cdots$ and $x_{n}$ is $A_{n}^{i}$

then $y$ is $B^{i}$,

と表される。

\section{標準的な推論手続き}

1) 入力 $x^{0}=\left(x_{1}^{0}, \ldots, x_{n}^{0}\right)$ に対して, 前提部の第 $i$ ル 一ルとの一致の度合い $w^{i を}$

$$
w^{i}=A_{1}^{i}\left(x_{1}^{0}\right) \times \cdots \times A_{n}^{i}\left(x_{n}^{0}\right)
$$

によって求め, 結論部の $B^{i}$ を求める.

2 ）重心法によって $B^{i を}$ 非ファジィ化する:

$$
b^{i}=\int B^{i}(y) y d y / \int B^{i}(y) d y .
$$

3 ）重み $w^{i}$ 基づく $b^{i}$ 重みつき平均值によって, 推論值 $\hat{y}$ を求める :

$$
\hat{y}=\sum_{i=1}^{m} w^{i} b^{i} / \sum_{i=1}^{m} w^{i} .
$$

注：2）の結果，モデルは

$R^{i}$ : If $x_{1}$ is $A_{1}^{i}$ and $\cdots$ and $x_{n}$ is $A_{n}^{i}$ then $y$ is $b^{i}$, すなわち，TSK モデルの特別な場合に帰着する。

本論文の，システム決定の標準的なプロセスは既出 の表 2 のとおりである．同定法については，すでに第 II部 6 節でふれている。参照されたい。

構造同定 I a (入力変数の候補の発見) 入力変数の 候補の決定はヒューリスティックになされる.ただし， 論文中では具体的な方法についてはふれていない。

構造同定 Ib（有意な入力变数の発見） GMDH (group method of data handling) 法における正規 化基準 regularity criterion $(R C)$ による $R C$ が増加 するまで変数を1つずつ增やしていく．

構造同定 $11 \mathrm{a}$ (入出力ルール数の決定） ルール数はク ラスタ数によって定まる。ここでクラスタは出力空間 のクラスタで，FCM (ファジィ c-平均) アルゴリズム により求められる.クラス夕数の決定は福山-菅野の指 標 $S(c)$ による（[26])。なおウェイト $m$ に関しては, 1.5 と3.0のあいだとのみ記述(それ以上の言及はない)。 クラスタリングの妥当性については第IV部13.4節参照.
構造同定 $11 \mathrm{~b}$ (入力空間の分割） 入力空間のクラスタ のクラスタ $A_{i}$ は出力空間のクラスタ $B$ を射影によって 得られる。（得られるクラス夕は，一般に凸ではない， そこで凸近似し，次いで台形近似する。）

この結果, 'If $x_{i}$ が (入力空間の) クラス夕 $A_{i}$ に属し ていれば, then $y$ は (出力空間の) クラスタ $B$ に属す るというルールが得られる。

なお，入力空間のファジィクラス夕は単峰とは限ら ず，2つ以上のクラスタが得られる場合がある。この ときは $1 つ の B$ につ以上のルールが対応することに なる。

パラメータ同定 凸ファジィ集合は台形型ファジィ集 命で近似される。台形型ファジィ集合は 4 つのパラメ 一夕 $p_{1}, p_{g}, p_{3}, p_{4}$ で決まる。それらは 6 ステップのア ルゴリズムで同定される。

\section{検証例}

1. 非線形システム $(\mathrm{a}, \mathrm{b}, \mathrm{c} ， \mathrm{~d}) 。$ ．ファァジィシ ステムモデル (a, d). 3. Box and Jenkinsのガス 炉 (b, c, d)，4．化学プラントの操作 (a, c, d, e). 5 . 水浄化プロセスの操作 $(\mathrm{a}, \mathrm{c}, \mathrm{d})$ ）6 . 株価の変 動解析 $(\mathrm{a}, \mathrm{c})$.

ここで,

a）位置型のファジィモデル,b）位置一傾き型のファ ジィモデル，c）質的モデル，d）構造同定 I-入力変数 の選定, e）言語ルールの数の制御, f) 構造同定 II -ル ールの数，g）パラメー夕同定 である。

\subsection{ETG モデル—Emami et al.の解法}

Emami らは [19] で Sugeno and Yasukawa [83] のモデルと同定法に改良を加えた，1）統一的なパラ メトリック推論の定式化，2）クラスタリングアルゴ リズムの改善，および， 3 ) 有意な入力変数とそのメ ンバーシップ関数の效果的な選定法を提案し, [20] で 理論的根拠を与えた。

基本モデル は $m$ 個の条件文

$$
\begin{array}{r}
\text { IF } x_{1} \text { is } A_{1}^{i} \text { AND } \cdots \text { AND } x_{n} \text { is } A_{n}^{i} \\
\text { THEN } y \text { is } B^{i}, i=1, \ldots, m
\end{array}
$$

をALSOで結んだものである.

基本モデルには 3 つの結合演算子 AND, IF-THEN, およびALSO が含まれている.ANDは Schweizer and Sklarのパラメトリックtーノルムを用いる. IF-THEN として，2つの含意すなわち Mamdaniの合接的含意 ( $\mathrm{t}$-ノルムを用いる) と形式論理的（離接的）含意 $(\mathrm{t}-$ 
コノルムを用いる）を採用した。ささらに ALSO とし て, 合接的推論では OR ( $\mathrm{t}$ コノルム) を, 離接的推論 では AND ( $\mathrm{t}$ ノルム)を用いた（以上の $\mathrm{t}$ ーノルム， $\mathrm{t}-$ コノルムにはパラメータ $p, q$ が含まれている.)

統一的推論機構 Mamdani $の$ 合接的推論の絬果 $F_{\mathrm{M}}(y)$ と形式論理の離接的推論の結果 $F_{\mathrm{L}}(y)$ を

$$
F(y)=\beta F_{\mathrm{L}}(y)+(1-\beta) F_{\mathrm{M}}(y)
$$

で結合する (パラメータ $\beta$ を含む).

非ファジィ化 Yager らの BADD (basic defuzzification distribution）法による (パラメー夕 $\alpha$ を含む).

システム同定 以下の表 7 に示すとおりである.特に， パラメータ同定では，上に示した 4 つのパラメータの 同定を意味する。

表 7 システム同定

\begin{tabular}{l|l}
\hline \multirow{2}{*}{$\begin{array}{l}\text { 構造 } \\
\text { 同定 }\end{array}$} & ルール生成 \\
\cline { 2 - 2 } $\begin{array}{c}\text { パラメータ } \\
\text { 同定 }\end{array}$ & 入力メンバーシップ選定 \\
\cline { 2 - 2 } & 推諭パラメータ修正 \\
\hline
\end{tabular}

入力变数の選定に関して, Sugeno-Yasukawa の方法, Takagi-Hayashiの方法 (ニューラルネットワーク), Lin et al.の方法 (ファジィ曲線)をサーベイした後で, 新手法を提案した．また，福山一菅野のものとは異なる クラスタ妥当性指標を提案した（第IV部13.4節参照）.

\section{検証例}

1. 非線形システム

2. Box and Jenkinsのガス炉

\begin{tabular}{|c|c|}
\hline Model & PI PV $\mathrm{FI}$ \\
\hline Emami et al. & $0.1584 \quad 3 \quad 6$ \\
\hline
\end{tabular}

\section{0 その他の手法}

\subsection{FNN——ァジィニューラルネットワーク}

Lin et al. [54］はファジィとニューラルネットワー クの観点を比較して, 表 8 を得た。

[1] Horikawa et al. ([32]，92年)

Horikawa et al. [32]はいう：「ファジィモデリン グはすぐれた手法だが，ルールの同定とメンバーシッ プ関数の調整に困難がある。逆伝播（BP）アルゴリズ ムを用いたファジィ・ニューラルネットワークは, 専 阴家の推測データからの学習を通じて，これらを同時 に解くことができる.」と。
表 8 ファジィと NNの対応

\begin{tabular}{|c|c|c|}
\hline & ファジィ & NN \\
\hline 1 & 有效変数の選定 & 有効変数の選定 \\
\hline 2 & ルール数・MF の決定 & NW 構造と初期重み \\
\hline 3 & MF の調整 & NWの学翟 \\
\hline 4 & 不要なルールの沜除 & 不要な神経の削除 \\
\hline
\end{tabular}

ファジィ推論 reasoning のパラメー夕を $\mathrm{NN}$ の連結 の重み connenction weightとして表す.ファジィ推論 は sup-productとする。

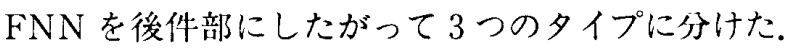
第 I は定数, 第 II は I 次関数, 第IIIはファジィ変数の 3つで，それぞれのタイプの FNN が対応する.

検証例は姜一菅野 [37］の非線形システム。

[2] Lin et al. ([54]，95年)

Lin et al. [54]はファジィ曲線を導入し，それによ って有效变数の選定, モデル構造の決定（必要なルー ル数の決定), ファジィ・ニューラルネットワークの初 期重みの決定を可能にした。

検証例 Box and Jenkins のガス炉.

\begin{tabular}{c|ccc}
\hline Model & PI & PV & FI \\
\hline Lin et al. & 0.071 & 5 & 4 \\
\hline
\end{tabular}

このほか, Sugeno and Yasukawa [83] の非線形 関数, 大阪湾の酸素需要, および株洒の変動解析など.

\section{2 その他のモデル}

[1] Joo et al. ([36]，97年)

本論文で提案されているモデルは,

$R^{i}$. If $x_{1}$ is $A_{1}^{i}$ and $\cdots$ and $x_{n}$ is $A_{n}^{i}$

$$
\text { then } y^{i}=w^{i} a_{i}+b_{i}
$$

である。ここで, $w^{i}$ は前提部の一致度である，彼らは $\mathrm{GA}$ ハイブリッド法によって解を求めた。

\section{検証例}

1. Box and Jenkinsのガス炉

\begin{tabular}{c|ccc}
\hline Model & PI & PV & FI \\
\hline Joo et al. & 0.166 & 2 & 6 \\
\hline
\end{tabular}

2.ナビゲーション制御

[2] Delgado and Gómez-Skarmeta et al. ([16], 98年)

本論文で, Delgado らは，それまでのファジィモデ リングの手法を, 記述的方法と近似的方法とに分類し, 
そのうえで，これらの折哀法を提案した，そのモデル は

$R_{i j}:$ If $x$ is $A_{i}$ then $y$ is $B_{j}$ (ただし， $\left.x=\left(x_{1}, \ldots, x_{p}\right)\right)$ で，これに新たにルール の重み $w_{i j}$ を加えた。

検証例として, 倒立振子とBox and Jenkins のガス 炉を扱っている.(彼らはモデルの評䛧指標として、 $\sqrt{\mathrm{PI}}$ を採用している。）

\section{1 検証例の比較}

1. Box and Jenkinsのガス炉

表10 結果の一覧

\begin{tabular}{l|c|c|c}
\hline Model & PI & PV & FI \\
\hline \hline Box-Jenkins ('70) & 0.202 & 6 & - \\
\hline Linear model & 0.193 & 5 & - \\
\hline \hline Tong [90] ('78) & 0.469 & 2 & 19 \\
\hline Pedrycz [72] ('84) & 0.320 & 2 & $(81)$ \\
\hline Xu et al. [105] ('87) & 0.328 & 2 & $(25)$ \\
\hline \hline Sugeno-Tanaka [82] ('91) & 0.359 & 2 & 2 \\
\hline Sugeno-Tanaka [82] ('91) & 0.068 & 6 & 2 \\
\hline Wang et al. [98] ('96) & 0.059 & 6 & 2 \\
\hline Kim et al. [42] ('97) & 0.055 & 6 & 2 \\
\hline Gómez-Skarmeta et al. [29]、('99) & 0.157 & 2 & 2 \\
\hline \hline Sugeno-Yasukawa [83] ('93) & 0.190 & 3 & 6 \\
\hline Emami et al. [19] ('98) & 0.158 & 3 & 6 \\
\hline \hline Joo et al. [36] ('97) & 0.166 & 2 & 6 \\
\hline \hline Lin et al. [54] ('95) & 0.071 & 5 & 4 \\
\hline
\end{tabular}

表において，PI は評䛧指標，PVは予測变数の数， FI はルール数，（）内は参照ファジィ集合の数をそ れぞれ示す。

表の最初のグループは非ファジィ，2つ目はファジ 1関係方程式, 第 3 は TSK モデル, 第 4 はSY モデル, 第 5 は他のモデル，最後はFNN 法による結果をそれぞ れ示寸。

2. Sugeno-Yasukawa の非線形モデル

$$
y=\left(1+x_{1}^{-2}+x_{2}^{-1.5}\right)^{2}, \quad 1 \leq x_{1}, x_{2} \leq 5
$$

\begin{tabular}{l|c|c|c}
\hline Model & PI & PV & FI \\
\hline Sugeno-Yasukawa [83] & 0.010 & 2 & 6 \\
\hline Emami et al. [19] & 0.011 & 2 & 8 \\
\hline
\end{tabular}

\section{IV 関連技法}

システムの一部分を構成するさまざまな技法がある. ここでは，あたかも，システムモデリングの問題の一
部をなしているように解説しているが，じつはそれら 自身が独立した1つの技法でもある。

第IV部では，そうした技法について概説する。

\section{2 基礎的技法}

\section{［1］参照ファジィ集合とファジィ弁別法}

ファジィ集合の計算を簡単化するために，参照ファ ジイ集合とファジィ弁別法が Willaeys et al. [102] に よって導入された。実数空間 $\Omega$ の $c$ 個のファジィ集合 $R_{1}, \ldots, R_{c}$ は, 任意の点 $x$ で, 少なくとも 1 つの $i$ が 存在して $R_{i}(x)>0$ となるとき, 参照ファジィ集合とい j.このとき, $\Omega$ のファジィ集合 $X$ は $\left(p_{1}, p_{2}, \ldots, p_{c}\right)$ によって表される。ここで

$$
p_{i}=\sup _{x \in \Omega}\left[X(x) t R_{i}(x)\right]
$$

である $(t$ は枋ノルム $)$ ここのよにしてファジィ集令 の計算を簡単化する手法をファジィ弁別法という。

Kroll [49］はこの手法を多次元化し(これを多次元 参照ファジィ集合という)，彼自身およびGómez-Skarmeta et al. [29] はファジィモデリングに心用した。

参照ファジィ集合の決定は, 統計, クラスタリング, 主観的方法などがあるが, 決定的方法はない(Wang et al. [97]).

\section{[2] 入力変数の選定}

入力変数選定の手法は Sugeno-Yasukawa [83]の 方法, Takagi-Hayashiの方法 (ニューラルネットワ 一ク), Lin et al. [53, 54] の方法 (ファジィ曲線) などが提案されている. Emami et al. [19] によって サーベイされている。

Sugeno and Yasukawa [83］（正規化基準）, Takagi and Hayashi［84］（ファジィ推論ニューラルネット ワーク), Lin and Cunningham [53]（ファジィ曲線)， Emami et al. [19］（非有意性測度）などである。

\section{検証例}

1. Box and Jenkinsのガス炉。 2 . 大阪湾の酸素 需要. 3 . 株価の変動解析.

\section{3 ファジィクラスタリング}

空間をいくつかの部分集合に分類することがしばし ば求斿れる．所属（クラス）の判別した学習用のデ 一夕が与えられている場合と，そうした情報がいっさ い与えられていない場合とがある。前者をパタン分類 pattern classification といい, 後者をクラスタリング clustering という. 


\section{1 パタン分類}

パタン分類については, Simpson [79] や Nozaki et al. [67] などの概説がある。後者は，さらに，パタン 分類に関する技法を，ファジィ関係(ファジィルール， 言語認識), ファジィパタンマッチング,ファジィクラ スタリング，その他の技法に分類してそれぞれについ ての解説を行っている,

パタン分類の手法には, 超矩形 hyperbox に基づく手 法 (Simpson [79]-Abe et al. [2]）と適応型ファジィ ルールに基づく手法(Ishibuchi と Nozaki ら $[33,67]$ ) とがある。いずれも検証例として，あやめ（iris）の分 類に加え，いくらかの例をあげている.

Simpson [79] はファジイ超矩形 hyperbox を定義 し，それを張りあわせて分類領域とする手法を提案し た。

Abe et al. [2] は Simpson [79] の超矩形 hyperbox (Abe らはこれを活性的 activation 超矩形と呼ぶ) に加えて、新たに抑制的 inhibition 超矩形を導入しっこ れらによって数值入力ー出力データからファジィルール を引き出方方法を提案した。

Ishibuchi and Nozaki et al. [33] はパタン笁間の ファジィ分割, 各領域でのファジィルールの同定とい う2つの段階からなるパタン分類を提唱した。異なっ た大きさのファジィ分割を作り，各分割に対してファ ジィルールを定義し，それらのファジィルール表を重 ね命わせるという方法である. Nozaki and Ishibuchi et al. [67] は適応的ファジィルールに基づく分類シス テムを提案した。

\section{2 ファシ்ィクラスタリング}

クラスタリングはよく使われているパタン分類の非 監督 unsupervised 手法である (Kothari et al. [47]).

「クラスタ分析は一群のデータをいくつかの数の部 分群に分割することによってなされる。それらのクラ ス夕(部分群)の内部は何らかの意味での近さ closedness あるいは相似性 similarity を示す.」(Gath et al. [28])

ファジィクラスタリングについては宮本その他によ る解説がある([66]，第 7 章)。学会誌第 8 卷 [65] は ファジィクラスタリングの特集を組んでいる。さらに, Bezdek et al.の成書 [11] がある.

Gath et al. [28] は，1）クラス夕の数は一般には 事前には知り得ない(クラス夕妥当性 validity 基準が 必要である)，2）クラス夕のゆ心の性質や位置は事前 には知り得ない(初期の推理が必要である)，3）クラ ス夕の形状, クラス夕の密素, 冬クラス夕を構成する 点の数などの变動がきわ好大き，といった困難を 指摘している.
以下で用いる記号のうち重要なものをあげておく： ・p 次元データベクトル空間神のデータ

$$
X=\left\{x_{1}, \ldots, x_{k}, \ldots, x_{n}\right\}, \quad x_{k} \in \mathbb{R}^{p}
$$

を $c$ 個のクラス夕に分割する。すなわち, $c \times n$ 行列 $U=$ $\left[u_{i k}\right]$ をクラス夕行列という。 ここで, $u_{i k}(k=1, \ldots$, $n, i=1, \ldots, c)$ は対象 $x_{k}$ が第 $i$ クラス夕に属するメン バーシップの度命いである。

(1) $0 \leq u_{i k} \leq 1$,

(2) $\sum_{i=1}^{c} u_{i k}^{i}=1$.

(注：(13.1) 式は全てのクラスタリングアルゴリズム で要請されるわけではない.)

- 第 $i$ クラスタの重心 centroid $v_{i} \in \mathbb{R}^{p}(i=1, \ldots$, c)で装し， $V=\left(v_{1}, \ldots, v_{c}\right)$ を重心べクトルという。 ファジィクラスタリングの手法には，13.3節で解説 するファジィ $\mathrm{c}^{-}$平均 $(\mathrm{FCM})$ クラスタリング・アルゴ リズムのほかに, Keller et al. [39] の $K$-最近近傍ア ルゴリズム, Yager et al. [110] の（'簡単かつ效果的 な’）山岳法, およびChiu [14］の改善川岳法などがあ るが，詳細は省略する。

\subsection{FCM——ァシ்ィ c-平均クラスタリングアルコ リズム}

ファジィ c-平均 (FCM) クラスタリング・アルゴリ ズムはBezdek [9] によって導人された.Kwon [51] は「この手法はこの 20 年のあいだで非監督分類のファ ジィ理論の手法として, 理論的にも応用面でも傑出し た方法である.」と述べている。

FCM は下の(13.3)を最小にするクラス夕構成である. アルゴリズムは以下のとおりである：

1）初期ベクトルの設定：点 $x_{k}$ が第 $i$ クラス夕に属 する初期メンバーシップ值 $u_{i k}$ を(13.1)を満たすように 設定する。

2 ）重心の計算：(2)によってクラスタの重心 $v_{i}, i=$ $1, \ldots, c$ を

$$
v_{i}=\left\{\sum_{k=1}^{n}\left(u_{i k}\right)^{m} x_{k}\right\} /\left\{\sum_{k=1}^{n}\left(u_{i k}\right)^{m}\right\} .
$$

によって計算する。ここで, $m(>1)$ をデルの重み指 数 exponent（ファジイネス指数 index）である。

3 ) メンバーシップの更新：最新フメンバーシップ 值 $u_{i k}$ を

$$
u_{i k}=\frac{\left(1 /\left\|x_{k}-v_{i}\right\|_{A}^{2}\right)^{1 /(m-1)}}{\sum_{j=1}^{c}\left(1 /\left\|x_{k}-v_{j}\right\|_{A}^{2}\right)^{1 /(m-1)}}
$$

を用いて更新する。

4)くり返し：2）と3）を 


$$
J_{m}(U, V ; X)=\sum_{i=1}^{c} \sum_{k=1}^{n}\left(u_{i k}\right)^{m}\left\|x_{k}-v_{i}\right\|_{A}^{2} .
$$

がもはや減少しなくなるまでくり返す。

Al Sultan et al. [1] は FCM 法について論じてい る.

\section{4 クラスタの妥当性}

\section{クラスタの妥当性とは何か}

Pal and Bezdek［68］はクラスタについて簡単に概 観して,問題を次の 3 つの閜いに集約した. (Bezdek and Pal [12］も参照のこと.ただ，そこで扱われているの は FCM ではなく HCM-Hard c-means クラスタリン グであるが.)

Q 1 ）Xはクラス夕構造をもっているか。一クラ 又夕傾向の探求。

Q2）Xがクラス夕構造をもっているとして，それ をどのように見出すか。一五ラス夕分析.

Q 3 ）クラス夕構造が胃出されたとして,我々はその 妥当性 valisityをどのようにして知りうるか。一クラ 又夕妥当性:

Bensaid and Bezdek et al. [6] 寻妥当性指標につ いて詳しい論評がある。

\section{クラスタの妥当性を測る基準}

Gath et al. [28] は，データの部分群への “最適の

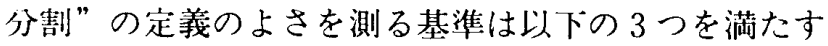
ことが要請される：

1 ）結果のクラスタは明確に分離されている

2 ）クラスタの体積は最小であること

3 ）クラスタの重心の近くに最大数のデータ点が集 中していること

こうした考察に基づき, Gath et al. [28] は2つの 基準, 超体積 hypervolume $F_{H V}$ と密度 (平均分割密度)

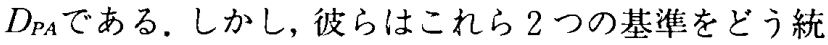
合するかについてはふれていない。

これまで多くの指標が提案された。最も早いのが(た だしクリスプなクラスタリングに対する指標だが) Dunn [18］の分離指標 $D_{1}$ で,クラス夕間の距離対クラスタの 直径の此に基づく指標である（ $c, n$ が大きくなると き）計算量が增大するという欠点をもつといわれてい

る (Xie et al. [103]).

ファジィ・クラスタリングについては, Bezdek [7] （または [8］か？）の分割係数 $F$ が最も早く，その後 も多数の指標が提案された. (それらを追うだけでも 1 冊の本ができそうである.)

Gunderson [30］は分離係数を導入した．この係数
は, Pal and Bezdek [68] によれば， $U, V ， X$ を 全て(陽に)用いた初めての指標である。(ただし，Xie et al. [103]によれば，クラスタリング結果をクリス プ化する。クリスプ化は唯一でなく，したがって，そ の係数も唯一には決まらないという短所をもつという。)

どの指標も緊密性（小さい方がよい）と分離性（大 きい方がよい）を基礎においている。ある指標はそれ らの差に，別のあるものは比に基づいている。

緊密性 compactness

(1) $J_{m}(U, V ; X)=\sum_{i=1}^{c} \sum_{k=1}^{n}\left(u_{i k}\right)^{m}\left\|x_{k}-v_{i}\right\|_{A}^{2}$.

分離性 separation

(1) クラスタ中心の分離

$$
\mathrm{MD}=\frac{1}{c} \sum_{i=1}^{c}\left\|v_{i}-\bar{x}\right\|_{A}^{2} .
$$

(2) FSのクラス夕間の距離

$$
K_{m}(U, V ; X)=\sum_{i=1}^{c} \sum_{k=1}^{n}\left(u_{i k}\right)^{m}\left\|v_{i}-\bar{x}\right\|_{A}^{2} .
$$

（3） ETGのクラスタ間の改善距離

$$
K_{m}^{\prime}(U, V ; X)=\sum_{i=1}^{c} \sum_{k=1}^{n}\left(u_{i k}\right)^{m}\left\|v_{i}-\bar{x}_{m}\right\|_{A}^{2},
$$

ここで

$$
\bar{x}_{m}=\sum_{i=1}^{c} \sum_{k=1}^{n}\left(u_{i k}\right)^{m} x_{k} / \sum_{i=1}^{c} \sum_{k=1}^{n}\left(u_{i k}\right)^{m}
$$

である. $\left(\bar{x}_{m}\right.$ の定義で， $u_{i k}$ が $m$ 乗されている点が改善 点である.)

(4) クラス夕間の最小距離

$$
\left(d_{\min }\right)^{2}=\min _{i \neq i^{\prime}}\left\|v_{i}-v_{i^{\prime}}\right\|^{2} .
$$

\subsection{1 妥当性指標 $\}$}

Bezdek の分割係数 coefficient ([7]，74年)

Bezdek の分割係数 $F$ は

$$
F=\frac{1}{n} \sum_{i=1}^{c} \sum_{k=1}^{n}\left(u_{i k}\right)^{2}
$$

で定義される。

\section{差型指標}

・福山一菅野の指標（[26]，89年)

$$
v_{F S}(U, V ; X)=J_{m}(U, V ; X)-K_{m}(U, V ; X) .
$$


(Pal and Bezdek [68］は,「第 2 項 $K_{m}$ の意味が明ら かでない.」という.)

•Emami らの指標（[19]，98年）

$$
s_{c S}(U, V ; X)=J_{m}(U, V ; X)-K_{m}^{\prime}(U, V ; X) .
$$

\section{比型指標}

•Xie-Beni の指標（[103]，91年）

$$
v_{X B}=\frac{J_{2}(U, V ; X)}{n \cdot\left(d_{m i n}\right)^{2}}
$$

この定義で, $J_{2}(U, V ; X)$ のパラメータ 2 をモデルの 重み指数 $m$ で代えて $J_{m}(U, V ; X)$ としたとき得られる 指標を拡張された指標という。

・Kwonの指標（[51]，98年）

$$
v_{K}(U, V ; X)=\frac{J_{2}(U, V ; X)+\mathrm{MD}}{\left(d_{\min }\right)^{2}} .
$$

\section{混合型指標}

・Zahid らの指標 ([117]，99年)

Zahid et al. [117] は新しい指標を提案した。ここ で

$$
\begin{aligned}
& \mathrm{SC}=\mathrm{SC}_{1}(U, V ; X)-\mathrm{SC}_{2}(U), \\
& \mathrm{SC}_{1}(U, V ; X)=S / \pi, \quad \mathrm{SC}_{2}(U)=\mathrm{FS} / \mathrm{FC}
\end{aligned}
$$

で，FSおよびFCは，それぞれ

$$
\begin{aligned}
& \mathrm{FS}=\sum_{i=1}^{c-1} \sum_{\mathrm{r}=1}^{c-i} \frac{\sum_{k=1}^{n} \min \left(u_{i k}, u_{r+i, k}\right)^{2}}{n_{i, r+i}}, \\
& \mathrm{FC}=\sum_{k=1}^{n}\left(\max _{1 \leq i \leq c} u_{i k}\right)^{2} / n_{\cup}
\end{aligned}
$$

である. $\left(n_{\cup}=\sum_{k=1}^{n}\left(\max _{1 \leq i \leq c} u_{i k}\right) ?\right)$

\section{指標の改良}

Hathaway and Bezdek [31]は特別な形の指標を改 良して，これと同等な一般的な手法によりうることを 示した。

\section{各指標の特徵}

Bezdekの分割係数 $F$ については，クラスタがよく 分離している（重複所属が少ない）とき $F$ は 1 に近づ く(したがって，Fは大きければよい)。しかし，幾何 学的性質との関連が小さいこと, $c$ に関して単調減少だ という久点をもつ。ただし，その後に提唱された多く
の指標も，Fと同様の欠点をもつといわれる (Xie et al. [103] の指摘).

$\mathrm{Pal}$ and Bezdek [68] はモデルの重み指数 $m$ の影 響を調べ, 福山らの抬標は $m$ の雨端 $(m \rightarrow 1$ または $m$

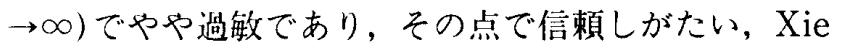
らの指標がいくらかまさる，と述べている.

Xie-Beni [103］の指標は $c$ が大きくなって $n$ に近 づくとき単調に減少する，彼らの検証例として，北極 星の周りの星の分布（Gunderson［30]）とICウェ7 アの色輪損傷とがある。

\section{妥当性指標の現状と今後}

最後に, Xie et al. [103] は妥当性指標の間題は未 解決であるといい，Pal and Bezdek［68］は（現在の） 妥当性指標が最良だとするクラス夕が真によいクラス 夕とは限らないと指摘したうえで，'Our goal? Do not give up.’と結んでいる.

\section{5 ファジィ c-平均クラスタリングの周辺}

Karayiannis and Bezdek [38]（ファジィ学習べク トル量子化法とファジィ c-平均クラスタリングとの関 係）や Krishnapuram et al. [48]（ファジィクラス夕 リングへの可能性に基づく接近法)などの考察がある. Bensaid et al. [6] はファジイクラスタリング・アル ゴリズムから出発して，これに份裂一合併をほどこす新 たなクラスタリングを構成法を提唱した。

\section{4 その他の話題}

\section{ファジィルールの抽出}

L. X. Wang et al. [99] は数值データからファシ்イ ルールを生成する新なな手法を提唱した. Benítez et al. [3，4，5] はニューラルネットによるファジィ制御の ルールの獲得の問題を論じている。

\section{非ファジィ化}

Jiang et al. [35] は「非ファジィ化はファジィシス テムにとってきわめて重要な過程である。というのは, 理論的にも応用的にも，最終的にはクリスプな出力（制 御）が必要だからである.」と述べている。

非ファジィ化には，重心法：COA (center of area) または COG (center of gravity) や最大平均法：MOM (mean of maximum) は通常最大值基準 MC（max criterion)よりもよいふるまいをする。そして, Jiang et al. [35] に上れば, COA 戦略は MOM 戦略よりも いろんな面ですぐれている。

Filev と Yager は一連の論文 $[24,107,108]$ に拉 いて非ファジィ化を調べている［23，107］でBADD 
(BAsic Defuzzification Distribution) を，[108] で は, SLIDE (Semi LInear DEfuzzification) 法と修正 SLIDE 法を定義し，その性質を調べた。

このほか, Runkler et al. [76] は非ファジィ化戦略 に対して $4 つ の$ 制約と13の公理を設け，4つの“古典 的”な非ファジィ化演算子, MOM, COA (center of Area一一彼らはメディアムを用いた), COG およびCLA (center of largest area)を比較した.

このほか, Mabuchi [56], De Oliveira [17], Jiang et al. [35]，あるいはSaade [78] によって，さまざ まな非ファジィ化手法が提案されている.

\section{その後の展開}

カナダ在留中入手できなかった論文は帰国してから 徐々に補ったが，新たに探索は特にしなかった。この 分野のその後の展開についてはよくわからない.Fuzzy Sets and Systems 誌 Vol.118, No.2でファジイモデリ ングの特集が組まれているのを知ったが，この通覧で は取りあげなかった。

\section{謝辞}

「はじめに」でも書いたが，トロント大学の Türksen 教授の研究室にお世話になる機会がなかったならば, そして，教授の不断の励ましがなければこの「通覧」 は陽の目を見なかったに違いない。深甚の感謝を捧げ る. 阁研究室の大学院生 Özge Uncu 君には下書き(英 文)の段階で目を通して有益な助言をいただいた. Kemal Kilc 君には最初に読むべき論文を教えてもらった。両 君に感謝する。

注 以下の参考文献の全てを入手することができな かった。他の文献を通じて重要と思われたものは記載 してある。

\section{参考 文 献}

[1] K. S. Al Sultan and S. Z. Selim, Global algorithm for fuzzy clustering problem, Pattern Recognition, 26, 1357-1361, 1993

[2] S. Abe and M.-S. Lan, A method for fuzzy rules extraction directly from numerical data and its application to pattern classification, IEEE Trans. Fuzzy Systems, 3/1, 18-28, 1995

[3] J. M. Benítez, A. Blanco and I. Requena, An empirical procedure to obtain fuzzy rules using neural networkss, Proc. 6th IFSA Congress, Brazil, 663-666, 1995

[4] J. M. Benítez, A. Blanco, M. Delgado and I.
Requena, Neural methods for obtaining fuzzy rules, Math. Soft Computing, 3, 371-382, 1996

[5] J. M. Benítez, A. Blanco, M. Delgado and I. Requena, New aspects on extraction of fuzzy rules using neural networks, Math. Soft Computing, 5, 333-343, 1998

[6] A. M. Bensaid, L. O. Hall, J. C. Bezdek, L. P. Clarke, M. L. Silbiger, J. A. Arrington and R. F. Murtagh, Validity-guided (re)clustering with applications to image sementation, IEEE Trans. Fuzzy Systems, 4/2, 112-123, 1996

[7] J. C. Bezdek, Numerical taxonomy with fuzzy sets, J. Math. Biol., 1, 57-71, 1974

[8] J. C. Bezdek, Cluster validity with fuzzy sets, J. Cyber., 3, 58-72, 1974

[9] J. C. Bezdek, Pattern recognition with fuzzy objective function algorithms, Plenum, New York, 1981

[10] J. C. Bezdek, Editorial: Fuzzy models — What are they, and why?, IEEE Trans. Fuzzy Systems, 1/1, 1-6, 1993

[11] J. C. Bezdek, J. Keller, R. Krisnapuram and N. R. Pal, Fuzzy models algorithms for pattern recognition and image processing, Klauer Academic Pub., 1999

[12] J. C. Bezdek and N. R. Pal, Some new indexes of cluster validity, IEEE Trans. Syst. Man, Cybern., B-28/3, 301-315, 1998

[13] J. C. Bezdek and N. R. Pal, Two soft relatives of learning vector quantization, Neural Networks, 8/5, 729-743, 1995

[14] S. L. Chiu, A cluster estimation method with extension to fuzzy model identification, Proc. 3rd IEEE Internat. Congress on Fuzzy Systems, 1240-1245, 1994

[15] E. Czogała and W. Pedrycz, On identification in fuzzy systems and its applications in control problems, Fuzzy Sets and Systems, 6, 73-83, 1981

[16] M. Delgado, A. F. Gómez-Skalmeta and F. Martín, A methodology to model fuzzy systems using fuzzy clustering in a rapid-prototyping approach, Fuzzy Sets and Systems, 97, 287-301, 1998

[17] J. V. de Oliveira, A set-theoretical defuzzification method, Fuzzy Sets and Systems, 76, 63-71, 1995

[18] J. C. Dunn, Well separated clusters and optimal fuzzy partitions, J. Cybern., 4, 95-104, 1974

[19] M. R. Emami, I. B. Türksen and A. A. Goldenber$\mathrm{g}$, Development of a systematic methodology of fuzzy logic modeling, IEEE Trans. Fuzzy Systems, 6/3, 346-361, 1998

[20] M. R. Emami, I. B. Türksen and A. A. Goldenber$\mathrm{g}$, A unified parameterized formulation of reasoning in fuzzy modeling and control, Fuzzy Sets and Systems, 108, 59-81, 1999

[21] P. Eykhoff, System identification, parameter and state estimation, Wiley, London, 1974

[22] D. Filev, Fuzzy modeling of complex systems, 
Internat. J. Approx. Reason., 5, 281-290, 1991

[23] D. P. Filev and R. R. Yager, A generalized defuzzification method via BAD distributions, Internat. J. Intelligence Systems, 6, 687-697, 1991

[24] D. P. Filev and R. R. Yager, An adaptive approach to defuzzification based on level sets, Fuzzy Sets and Systems, 54, 355-360, 1993

[25] M. Friedman, M. Ming and A. Kandel, Fuzzy linear systems, Fuzzy Sets and Systems, 96, 201209, 1998

[26］福山義幸, 菅野道夫, Fuzzy C-Means 法における 分割数の新しい選択法, 第 5 们ファジィシステムシ ンポジウム講演論文集, $247-250,1989$

[27] B. R. Gaines, Sequential fuzzy system identification, Fuzzy Sets and Systems, 2, 15-24, 1979

[28] I. Gath and A. B. Geva, Unsupervised optimal fuzzy clustering, IEEE Patt. Anal, Machine Intell., 11/7, 773-781, 1989

[29] A. F. Gómez-Skarmeta, M. Delgado and M. A. Vila, About the use of fuzzy clustering techniques for fuzzy model identification, Fuzzy Sets and Systems, 106, 179-188, 1999

[30] R. Gunderson, Application of fuzzy ISODATA algorithms to star tracker pointing systems, Proc. 7th Triennial World IFAC Cong. (Helsinki, Finland), 1319-1323, 1978

[31] R. J. Hathaway and J. C. Bezdek, Optimization of clustering criteria by reformulation, IEEE Trans. Fuzzy Systems, 3/2, 241-245, 1995

[32] S. Horikawa, T. Furuhashi and Y. Uchikawa, On fuzzy modeling using fuzzy neural networks with the back-propagation algorithm, IEEE Trans. Neural Networks, 3/5, 801-806, 1992

[33] H. Ishibuchi, K. Nozaki and H. Tanaka, Distributed representation of fuzzy rules and its application to pattern classification, Fuzzy Sets and Systems, 52, 21-32, 1992

[34] R. Jain, Outline of an approach for the analysis of fuzzy systems, Int. J. Control, 23, 627-640, 1976

[35] T. Jiang and Y. Li, Generalized defuzzification strategies and their paremeter learning procedures, IEEE Trans. Fuzzy Systems, 4/1, 64-71, 1996

[36] Y. H. Joo, H. S. Hwang, K. B. Kim and K. B. Woo, Fuzzy system modeling by fuzzy partition and GA hybrid schemes, Fuzzy Sets and Systems, 86, 279-288, 1997

[37] 姜根澤, 营野道夫, ファジィモデリング, 計测自動 制御学会論文集, 23/6，650-652，1987

[38] N. B. Karayiannis and J. C. Bezdek, An integrated approach to fuzzy learning vector quantization and fuzzy c-means clustering, IEEE Trans. Fuzzy Systems, 5/4, 622-629, 1997

[39] J. M. Keller, M. R. Gray and J. A. Givens, Jr., A fuzzy $K$-nearest neighbor algorithms, IEEE Trans. Syst. Man., Cybern., SMC-15/4, 580-585, 1985

[40] W. J. M. Kickert, Towards an analysis of linguistic modeling, Fuzzy Sets and Systems, 2, 293-307,
1979

[41] D. Kim, Improving the fuzzy system performance by fuzzy system ensemble, Fuzzy Sets and Systems, 98, 43-56, 1998

[42] E. Kim, M. Park, S. Ji and M. Park, A new approach to fuzzy modeling, IEEE Trans. Fuzzy Systems, 5/3, 328-337, 1997

[43] P. E. Kloeden, Fuzzy dynamical systems, Fuzzy Sets and Systems, 7, 275-296, 1982

[44] T. Kohonen, The self-organizing map, Proc. IEEE, 78/9, 1464-1480, 1990

[45]近藤而：モデルの次数を推定する改纹形 GMDH, 計 测白動制御兴会論文集，22/9，928-934，1986

[46] B. Kosoko, Fuzzy systems as universal approximation, IEEE Trans. Comput., 43, 1329-1333, 1994

[47] R. Kothari and D. Pitts, On finding the number of clusters, Pattern Recgnition Letters, 20, 405-416, 1999

[48] R. Krishnapuram and J. M. Keller, A possibilistic approach to clustering, IEEE Trans. Fuzzy Systems, $1 / 2,98-110,1993$

[49] A. Kroll, Identification of functional fuzzy models using multidimensional reference fuzzy sets, Fuzzy Sets and Systems, 80, 149-158, 1996

[50] M. Kurano, M. Yasuda, J. Nakagami and Y. Yoshida, A limit theorem in some dynamic fuzzy systems, Fuzzy sets and Systems, 51, 83-88, 1992

[51] S. H. Kwon, Cluster validity index and fuzzy clustering, Electronics Letters, 34/22, 2176-2177, 1998

[52] R. Langari and L. Wang, Fuzzy models, modular networks, and hybrid learning, Fuzzy Sets and Systems, 79, 141-150, 1996

[53] Y. Lin and G. A. Cunningham III, A fuzzy approach to input variale identification, Proc. 3rd IEEE Internat. Confer., Fuzzy Systems, 2031 $-2036,1994$

[54] Y. Lin and G. A. Cunningham III, A new approach to fuzzy-neural system modeling, IEEE Trans. Fuzzy Systems, 3/2, 190-198, 1995

[55] J. Lygeros, A forml approach to fuzzy modeling, IEEE Trans. Fuzzy Systems, 5/3, 317-327, 1997

[56] S. Mabuchi, A proposal for a defuzzification strategy by the concept of sensitivity analysis, Fuzzy Sets and Systems, 55, 1-14, 1993

[57] M. Maeda and S. Murakami, A design for a fuzzy logic controller, Inform. Sci., 45, 315-330, 1988

[58] F. Matía, B. M. Al-Hadithi and A. Jiménez, On the global stability of Takagi-Sugeno general model, Math. Soft Computing, 6, 293-304, 1999

[59] C. McMillan and R. F. Gonzalez, Systems analysis - - a computer approach to decision models, 3rd ed., Richard D. Irwin, Inc., Illinois, 1973

[60）中森義料，ファジィモデリンク，オーム社， 1994

[61］中森義輝, 領家美奈, ファジィモデリング再考, 日 本ファジィ学会誌，5，453-464，1993

[62］中森義䊇，領家美奈，ファジィモデル構築のための 
超譛山体クラスタリング法, 日本ファジィ学会誌, 5, 537-547, 1993

[63] H. T. Nguyen and M. Sugeno Eds., Fuzzy Systems - Modeling and Control, Kluwer Academic Pub., 1998

[64] 西川智登, 清水静江, 経営のためのシステム工学, 朝含费店, 1990

[65］特集・ファジィクラスタリングとその灾用，日本フ アジィ学会誌, 8, 405-462, 1996

[66] 日本ファジィ学会編, ファジィとソフトコンピュー ティングハンドブック，共立出版，2000

[67] K. Nozaki, H. Ishibuchi and H. Tanaka, Adaptive fuzzy rule-based classification systems, IEEE Trans. Fuzzy Systems, 4/3, 238-250, 1996

[68] N. R. Pal and J. C. Bezdek, On cluster validity for the fuzzy c-means model, IEEE Trans. Fuzzy Systems, 3/3, 370-379, 1995

[69] N. R. Pal, J. C. Bezdek and E. C.-K. Tsao, Generalized clustering networks and Kohonen's self-organizing scheme, IEEE Trans. Neural Networks, 4/4, 549-557, 1993

[70] W. Pedrycz, An approach to the analysis of fuzzy systems, Int. J. Control, 34, 403-421, 1981

[71] W. Pedrycz, Numerical and applicational aspects of fuzzy relational equations, Fuzzy Sets and Systems, 11, 1-18, 1983

[72] W. Pedrycz, An identification algorithm in fuzzy relational systems, Fuzzy Sets and Systems, 13, 153-167, 1984

[73] W. Pedrycz, Identification in fuzzy systems, IEEE Trans. Syst. Man, Ceybern., SMC-14/3, 361 $-366,1984$

[74] W. Pedrycz, Relevancy of fuzzy models, Inform. Sci., 52, 285-302, 1990

[75] W. Pedrycz, Fuzzy modelling: Fundamentals, construction and evaluation, Fuzzy Sets and Systems, 41, 1-15, 1991

[76] T. A. Runkler and M. Glesner, A set of axioms for defuzzification strategies towards a theory of rational defuzzification operators, Proc. 2nd IEEE Internat. Conf. on Fuzzy Systems, San Franciso, 1161-1166, 1993

[77] 領家美奈, 中菻義晄, 田村坦之, 高木・管野モデル の逆問題の解法，十本ファジィ学会誌，10, 541-547, 1998

[78] J. J. Saade, A unifying approch to defuzzifiction and comparison of the outputs of fuzzy controllers, IEEE Trans. Fuzzy Systems, 4/3, 227-237, 1996

[79] P. K. Simpson, Fuzzy min-max neural networks - Part 1: Classification, IEEE Trans. Neural Networks, 3/5, 776-786, 1992

[80] M. Sugeno and G. T. Kang, Fuzzy modelling and control of multilayer incinerator, Fuzzy Sets and Systems, 18, 329-346, 1986

[81] M. Sugeno and G. T. Kang, Structure identification of fuzzy model, Fuzzy Sets and Systems, 28, 15-33, 1988
[82] M. Sugeno and K. Tanaka, Successive identification of a fuzzy model and its applications to prediction of a complex system, Fuzzy Sets and Systems, 42, 315-334, 1991

[83] M. Sugeno and T. Yasukawa, A fuzzy-logicbased approach to qualitative modeling, IEEE Trans. Fuzzy Systems, 1/1, 7-31, 1993

[84] H. Takagi and I. Hayashi, NN-driven fuzzy reasoning, Internat. J. Approx. Reason., 5, 191212, 1991

[85] T. Takagi and M. Sugeno, Fuzzy identification of systems and its applications to modeling and control, IEEE Trans., Syst. Man, Cybern., SMC-$15 / 1,116-132,1985$

[86]田中英夫, ファジィモデリングとその忘用, 朝倉㫮 店, 1990

[87] R. Thawonmas and S. Abe, Function approximation based on fuzzy rules extracted from par. titioned numerical data, IEEE Trans. Man, Cybern. — Part B: Cybernetics, 29/4, 525-534, 1999

[88] R. M. Tong, A control engineering review of fuzzy systems, Automatica, 13, 559-569, 1977

[89] R. M. Tong, Analysis and control of fuzzy systems using finite discrete relations, Int. J. Control, 27, 431-440, 1978

[90] R. M. Tong, Synthesis of fuzzy models for industrial processes - some recent results, Int. J. General Systems, 4, 143-162, 1978

[91] R. M. Tong, The evaluation of fuzzy models derived from experimental data, Fuzzy Sets and Systems, 4, 1-12, 1980

[92] S. Tong and T. Chai, Direct adaptive control and robust analysis for unknown multivariable nonlinear systems with fuzzy logic systems, Fuzzy Sets and Systems, 106, 309-319, 1999

[93] I. B. Türkşen, Type I and Type II fuzzy system modeling, Fuzzy Sets and Systems, 106, 11-34, 1999

[94] W. Van Leekwijck and E. E. Kerre, Defuzzification: criteria and classification, Fuzzy Sets and Systems, 108, 159-178, 1999

[95] H. B. Verbruggen and P. M. Bruijn, Fuzzy control and conventional control: What is (and can be) the real contribution of Fuzzy systems?, Fuzzy sets and Systems, 90, 151-160, 1997

[96] L. Wang and R. Langari, Building Sugeno-type models using fuzzy discretization and orthogonal parameter estimation techniques, IEEE Trans. Fuzzy Systems, 3/4, 454-458, 1995

[97] L. Wang and R. Langari, Complex systems modeling via fuzzy logic, IEEE Trans. Syst., Man, Cybern., B-26/1, 100-106, 1996

[98] L. Wang and R. Langari, Sugeno model, fuzzy discretization, and the EM algorithm, Fuzzy Sets and Systems, 82, 279-288, 1996

[99] L. X. Wang and J. M. Mendel, Generating fuzzy rules by learning from examples, IEEE Trans. Syst., Man, Cybern., SMC-22/6, 1414-1427, 1992 
[100] S.-D. Wang and C.-H. Lee, Fuzzy system modeling using linear distance rules, Fuzzy Sets and Systems, 108, 179-191, 1999

[101] F. Wenstøp, Deductive verbal models of iorganizations, Int. J. Man-Machine Studies, 8, 293-311, 1976

[102] D. Willaeys and N. Malvache, The use of fuzzy sets for the treatment of fuzzy information by computer, Fuzzy Sets and Systems, 5, 323-327, 1981

[103] X. L. Xie and C. Beni, A validity measure for fuzzy clustering, IEEE Trans. Pattern Anal. Machine Intell., 13/8, 841-847, 1991

[104] C. W. Xu, Fuzzy systems identification, IEE Proc., 136-D, 146-150, 1989

[105] C. W. Xu and Y. Z. Lu, Fuzzy model identification and self-learning for dynamic systems, IEEE Trans. Syst. Man Cybern., SMC-17/4, 683689, 1987

[106] R. R. Yager, Aggregation operators and fuzzy systems modeling, Fuzzy Sets and Systems, 67, 129-145, 1994

[107] R. R. Yager and D. Filev, On the issue of defuzzification and selection based on a fuzzy set, Fuzzy Sets and Systems, 55, 255-271, 1993

[108] R. R. Yager and D. P. Filev, SLIDE: A simple adaptive defuzzification method, IEEE Trans. Fuzzy Systems, 1/1, 69-78, 1993

[109] R. R. Yager and D. P. Filev, Unified structure and parameter identification of fuzzy models, IEEE Trans. Syst. Man, Cybern., SMC-23/4, 1198 $-1205,1993$

[110] R. R. Yager and D. P. Filev, Approximate clustering via the mountain method, IEEE Trans. Syst. Man, Cybern., SMC-24/8, 1279-1284, 1994
[111] R. R. Yager and D. P. Filev, Essentials of fuzzy modeling and control, Wiley, New York, 1994

[112] J. Yen, L. Wang and C. W. Gillespie, Improving the interpretability of TSK fuzzy models by combaining global learning and local learning, IEEE Trans. Fuzzy Systems, 6/4, 530-537, 1998

[113] Y. Yoshida, M. Yasuda, J. Nakagami and M. Kurano, A limit theorem in dynamic fuzzy systems with a monotone property, Fuzzy sets and Systems, 94, 109-119, 1998

[114] Y. Yoshinari, W. Pedrycz and K. Hirota, Construction of fuzzy models through clustering techniques, Fuzzy Sets and Systems, 54, 157-165, 1993

[115] L. A. Zadeh, Fuzzy algorithms, Inform. Contr., $12,94-102,1968$

[116] L. A. Zadeh, Outline of a new approach to the analysis of complex systems and decision processes, IEEE Trans. Systems, Man, Cybern., SMC3/1, 28-44, 1973

[117] N. Zahid, O. Abouelala, M. Limouri and A. Essaid, Unsupervised fuzzy clustering, Pattern Recgnition Letters, 20, 123-129, 1999

[118] X. J. Zeng and M. G. Singh, Approximation theory of fuzzy systems - SISO case, IEEE Trans. Fuzzy Systems, 2/2, 162-176, 1994

[119] X. J. Zeng and M. G. Singh, Approximation theory of fuzzy systems - MIMO case, IEEE Trans. Fuzzy Systems, 3/2, 219-235, 1995

（2001年 3 月 30 日 受付）

[問い合わせ先］

中島 信之

930-8555 富山市五福3190 富山大学経済学部

TEL : 076-445-6475, FAX : 076-445-6419

e-mail:nakanobu@eco.toyama-u.ac.jp

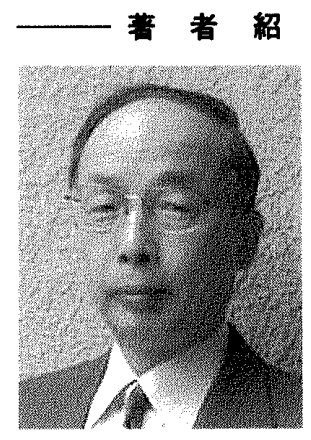
介
仲島 信之なかしまのふのり
富山大学経済学部
1965年 大阪大学大学院理学研究科修 士倸程修了, 大阪府立大学, 大阪大学助 手, 和歌山県立医科大学講師, 助教授を䅅 $\tau ， 1990$ 年 4 月より富山大学程消学部䅅 営学科教授、著書に「おはなしファジイ (日本規格協会, 共著)，「講座ファジィ第 2 巻, 第 1 章・ファジィ集命」(日刊工業 新聞社), 「社会科の数理・ファジイ理論 入阿」(裳華房, 共著)。「ファジィ数学の おはなし」(培風䗆)。工学博士. 